FIU Law Review

Spring 2010

\title{
The Vanishing Employee: Putting the Autonomous Dignified Union Worker Back to Work
}

Anne Marie Lofaso

West Virginia University College of Law

Follow this and additional works at: https://ecollections.law.fiu.edu/lawreview

Part of the Other Law Commons

Online ISSN: 2643-7759

\section{Recommended Citation}

Anne M. Lofaso, The Vanishing Employee: Putting the Autonomous Dignified Union Worker Back to Work, 5 FIU L. Rev. 495 (2010).

DOI: https://dx.doi.org/10.25148/lawrev.5.2.13

This Article is brought to you for free and open access by eCollections. It has been accepted for inclusion in FIU Law Review by an authorized editor of eCollections. For more information, please contact lisdavis@fiu.edu. 


\title{
The Vanishing Employee: Putting the Autonomous Dignified Union Worker Back to Work
}

\author{
Anne Marie Lofaso
}

\section{INTRODUCTION}

At age seventy-five, some are wondering, Whither the Board? What does the future hold for the National Labor Relations Board, that New Deal, inside-the-belt, administrative agency tasked by Congress with administering the National Labor Relations Act? ${ }^{1}$ Florida International University Law Review asks this question at a significant juncture in the NLRB's history. At the time this symposium took place, the normally five-member Board had been operating since December 31, 2007, that is, for 817 days, with only two members - Democratic Chairman Wilma Liebman and Republican Member Peter Schaumber - who during that time decided almost 600 cases. $^{3} \quad$ After operating for over two years under questionable authority, ${ }^{4}$ the NLRB became whole again when President Obama appointed Craig Becker and Mark Pearce, democrats with union backgrounds, to the Board only hours after the March 27, 2010, close of this symposium. ${ }^{5}$

\footnotetext{
Anne Marie Lofaso is an Associate Professor at West Virginia University College of Law. Dr. Lofaso gives many thanks to those who commented on early drafts of this article, especially Robert Bastress, Tom Cady, Ellen Dannin, David Gregory, Michael C. Harper, Jim Heiko, Jeff Hirsch, Kerri Stone, Marley Weiss, and to the West Virginia University College of Law Faculty. Thanks to Jenny Flanigan, Nicholas Stump, and Matthew T. Yanni for their research assistance and to the Bloom Junior Faculty Research Grant for its support of this project. Special thanks to Dean Alex Acosta, the FIU Law Review, the FIU faculty and staff, and all the invisible workers for their tireless work in putting together this important symposium. The author assumes responsibility for all errors.

1 NLRB v. Town \& Country Elec., Inc., 516 U.S. 85, 94 (1995); Sure-Tan, Inc. v. NLRB, 467 U.S. 883, 891 (1984); NLRB v. Yeshiva Univ., 444 U.S. 672, 693 n.1 (1980); Allied Chem. \& Alkali Workers v. Pittsburgh Plate Glass Co., 404 U.S. 157, 166 (1971); NLRB v. Hearst Publ'ns, Inc., 322 U.S. 111, 130 (1944).

March 26-27, 2010.

3 New Process Steel, L.P. v. NLRB, No. 08-1457, slip op. at 3 (U.S. June 17, 2010) (calculating that period in terms of approximately twenty-seven months).

4 Id. at 13-14 (holding that the NLRA does not authorize a two-member Board to issue decision).

5 Mike Hall, Obama Uses Recess Appointments for NLRB and Other Blocked Nominations, Mar. 29, 2010, http://blog.aflcio.org/2010/03/29/obama-uses-recess-appointments-for-nlrb-and-otherblocked-nominations/; see also Obama Appoints Becker and Pearce to the NLRB, American Rights at Worker, http://www.americanrightsatwork.org/eye-on-the-nlrb/blog/obama-appoints-becker-and-pearceto-the-nlrb-20100329-884-388.html (last visited Aug. 9, 2010).
} 
Dean R. Alexander Acosta and the Law Review have tasked the panelists not only with predicting the Board's future but also with commenting on the extent to which the Board's fate is to "wither" away. ${ }^{6}$ That pun on "w[h]ither" suggests that the Board is destined to dry up, to become sapless, to lose life, to shrivel from loss of bodily moisture. Typically, the withering process is slow (in this case three-quarters of a century), natural (in this case, the diminishing need, some suggest, for union representation), internal, and inevitable. ${ }^{8}$

In support of the position that the withering process is part of the natural aging of certain institutions in an advanced capitalist state, critics have offered several explanations for concluding that unions are no longer necessary or relevant. Some union critics argue that unions are no longer necessary because they have accomplished their core goals - the eight-hour day, better wages, and safer working conditions - through legislation. ${ }^{9}$ But that doesn't recount the entire story. After all, unions are at least as interested in job security as they are in these other subjects, and job security remains an important issue for workers, at least until economists figure out how to deal with cyclical unemployment. ${ }^{10}$ Others argue that, while unions may have been relevant in the industrial, manufacturing-based economy of the early twentieth-century United States, they are no longer relevant in today's knowledge-based economy. Those critics base their argument on the assumption that unions bargain collectively for a one-size-fits-all contract that favors seniority-based promotions and raises that ignore the

6 R. Alexander Acosta, Rebuilding the Board: An Argument for Structural Change, Over Policy Prescriptions, at the NLRB, 5 FIU L. REV. 347 (2010).

7 Merriam-Webster OnLine, http://www.merriam-webster.com/dictionary/wither (last visited Aug. 9, 2010).

8 See, e.g., James Sherk, Do Americans Today Still Need Labor Unions?, FredericksBurg Free LANCE-STAR, Mar. 30, 2008, at A1, available at THE HERITAGE Foundation, http://www.heritage.org/Research/Commentary/2008/04/Do-Americans-today-still-need-labor-unions.

9 For example, in 1938, Congress passed the Fair Labor Standards Act (FLSA), 29 U.S.C. $\S \S 201-219$, which requires employers to pay covered workers minimum wage rates, and forbids employers to employ covered workers "for a workweek longer than forty hours unless such employee receives compensation for his employment in excess of [forty] hours . . . at a rate not less than one and one-half times the regular rate at which he is employed." 29 U.S.C. $\S \S 206,207$ (a)(1) (2006). In 1970, Congress passed the Occupational Safety and Health Act (OSH Act), 29 U.S.C. $\S \S 651-678$, which places on employers both general and specific duties to maintain healthy and safe workplaces. In addition to passing these two congressional acts of general applicability, Congress and state legislatures have passed numerous other statutes to regulate workplace wages, hours, and safety.

10 See generally Anne Marie Lofaso, The Relevance of the Wagner Act for Resolving Today's JobSecurity Crisis, Labor and Employment Relations Association Proceedings of the 62nd Annual Meeting (forthcoming 2011); Anne Marie Lofaso, Talking Is Worthwhile: The Role of Employee Voice in Protecting, Enhancing, and Encouraging Individual Rights to Job Security in a Collective System, 14 EMP. RTS. \& EMP. POL'Y J.55 (2010). 
special talents of individual workers. ${ }^{11}$ That assumption is of course falsified by the existence of more elastic collective-bargaining agreements, such as the basic agreement between Major League Baseball and the Players Association, which expressly permits individual bargaining between clubs and players over salaries. ${ }^{12}$ But myth is often more influential than reality.

I have argued that the NLRA's protective cover has been eroded not so much by natural forces but by the cacophonous efforts of three government actors - Congress, the federal courts, and the NLRB itself. ${ }^{13}$ Together over time these players have reduced the Act's effectiveness as the national protector of industrial democracy by shrinking the contours of Section 7, weakening the economic weapons at a union's disposal, reinforcing a weak remedial scheme, diminishing worker voice by curbing workers' card-check options to express their desire for collective workplace representation, and restricting the statutory definition of employee. ${ }^{14}$ Coupling this three-part federal hymn with the agency's many structural problems - a two-member Board for 817 days and a drawn-out administrative process - has resulted in the persistence of union repression, ${ }^{15}$ notwithstanding national labor policy dedicated to "the practice and procedure of collective bargaining."

To accomplish my part in this law review symposium dedicated to understanding " $\mathrm{w}[\mathrm{h}]$ ither the Board," this article focuses on the statutory definition of employee to suggest that the legal mechanism for protecting workers is not necessarily withering away from natural processes but is being eroded (and in some cases massacred) by those legal institutions designed to protect them. In Section II, I explain why I chose to explore the statutory definition to demonstrate the erosion process. There, I briefly explain the significance of analyzing the statutory definition of employee as the gateway to all worker protection under the NLRA. In Section III, I deconstruct the statutory definition and show the extent to which it has narrowed over time. The article's constructive or perhaps reconstructive aspect, presented in concluding Section IV, suggests whither the law can go to rejuvenate labor.

\footnotetext{
11 See, e.g., Sherk, supra note 8.

12 See MLB.com, 2007-2011 Basic Agreement, http://mlb.mlb.com/pa/pdf/cba_english.pdf (last visited Aug. 9, 2010).

13 See generally Anne Marie Lofaso, The Persistence of Union Repression in an Era of Recognition, 62 ME. L. REV. 199 (2010) [hereinafter Union Repression]; Anne Marie Lofaso, September Massacre: The Latest Battle in the War on Workers' Rights Under the National Labor Relations Act, AM. CONST. SOC'Y FOR L. \& POL., (2008), http://papers.ssrn.com/sol3/papers.cfm?abstract_id=1133607 [hereinafter September Massacre].

14 See generally Union Repression, supra note 13; September Massacre, supra note 13.

15 See Union Repression, supra note 13; September Massacre, supra note 13.

1629 U.S.C. $§ 151$ (2006).
} 


\section{ThE STATUTORY DEFINITION OF EMPLOYEE IS SigNIFICANT} BECAUSE IT IS THE GATEWAY TO ALL WORKER PROTECTION UNDER $§ 7$

The heart of the National Labor Relations Act lies in Section 7, which defines the main rights granted under the NLRA. ${ }^{17}$ In its current statutory form, those rights are:

the right to self-organization, to form, join, or assist labor organizations, to bargain collectively through representatives of their own choosing, and to engage in other concerted activities for the purpose of collective bargaining or other mutual aid or protection, and shall also have the right to refrain from any or all such activities ... ${ }^{18}$

Reading the statutory language together with the relevant case law, we learn that the NLRA protects the rights of employees to:

- self-organize, ${ }^{19}$

- to form, join, or assist unions, ${ }^{20}$

- to bargain collectively through representatives chosen by employees through either a secret-ballot election or by card check, ${ }^{21}$

- to band together concerted for mutual aid or protection, ${ }^{22}$ and

17 Id. $\S 157$.

18 Id. The NLRA in its original form (the Wagner Act) only included the italicized language. Congress added the remaining language in 1947 with the Taft-Hartley amendments. The definition also includes an exception - "except to the extent that such right may be affected by an agreement requiring membership in a labor organization as a condition of employment as authorized in section 8(a)(3)" which is not relevant to the arguments presented here. Id.

19 The Board, with Supreme Court approval, has broadly interpreted "the right of employees to self-organize" as "necessarily encompass[ing] the right effectively to communicate with one another regarding self-organization at the jobsite." Beth Israel Hosp. v. NLRB, 437 U.S. 483, 491 (1978).

20 The Supreme Court has not fully defined what the meaning of the right to "form, join, or assist" a labor organization, but has articulated instances that the right does not include. For example, the Court has held that this right does not entitle nonemployee union organizers to trespass onto the employer's property to assist organization other reasonable alternatives exist. See Lechmere, Inc. v. NLRB, 502 U.S. 527, 533 (1992).

21 The Board, with Supreme Court approval, recognizes both secret-ballot elections and card checks as valid methods for determining a union's majority status. See NLRB v. Gissel Packing Co., 385 U.S. 575, 596 (1969). In NLRB v. Erie Resistor Corp., the Supreme Court also discussed the ways in which the right to strike supports collective bargaining: The NLRA's "repeated solicitude for the right to strike is predicated upon the conclusion that a strike when legitimately employed is an economic weapon which in great measure implements and supports the principles of the collective bargaining system.” NLRB v. Erie Resistor Corp., 373 U.S. 221, 233-34 (1963).

22 The Board, with Supreme Court approval, has broadly interpreted the mutual aid or protection clause to include the concerted activity of unorganized (at-will) employees. See NLRB v. Wash. Alumi- 
- $\quad$ to refrain from any or all such activities. ${ }^{23}$

Section 7 affords significant rights to workers. Together, these rights define what the international community calls the freedom of association a freedom so significant that it is one of the four fundamental principles that grounds the International Labour Organisation. ${ }^{24}$ Perhaps more tellingly, the "freedom of association and the effective recognition of the right to collective bargaining" is one of only four workers' rights that the ILO has declared fundamental. The other three are:

- the elimination of all forms of forced or compulsory labour,

- the effective abolition of child labour, and

- the elimination of discrimination in respect of employment and occupation. $^{25}$

Under United States federal law, these rights are only afforded to those workers who qualify as statutory employees. ${ }^{26}$ The Supreme Court recog-

num Co., 370 U.S. 9, 14-18 (1962) (holding that an employer may not discharge at-will employees for impermissibly and spontaneously walking out of their jobs to protest working conditions). The company's brief to the Supreme Court makes clear that it viewed the Board's decision as interfering with the employer's right to discharge within the confines of the at-will relationship. See Brief for Respondent, NLRB v. Wash. Aluminum Co., No. 61-464, 1962 WL 115796, at *28-33 (U.S. May 28, 1962).

23 The very little Supreme Court case law on the right to refrain has typically viewed that right as clarifying the principle of Board neutrality. As the Court explained in the context of holding that a union's offer to waive initiation fees for all employees who signed authorization cards before secretballot election interfered with employee's Section 7 right to refrain from union activities: "Any procedure requiring a 'fair' election must honor the right of those who oppose a union as well as those who favor it. The Act is wholly neutral when it comes to that basic choice." NLRB v. Savair Mfg. Co., 414 U.S. 270, 278 (1973); see also NLRB v. Granite State Joint Bd., 409 U.S. 213, 216 (1972) (recognizing that the right to refrain includes the right of a union member to resign lawfully within the confines of a union's constitution or bylaws).

24 ILO Constitution, Annex, Art. I(b), http:/www.ilo.org/public/english/bureau/leg/amend/ constitution.pdf (last visited Aug. 9, 2010). The ILO is "the world's only tripartite multilateral agency." It created as part of the Treaty of Versailles (1919) "that ended World War I, to reflect the belief that universal and lasting peace can be accomplished only if it is based on social justice," and "is dedicated to bringing decent work and livelihoods, job-related security and better living standards to the people of both poor and rich countries." See ILO, Mission and Objectives, http://www.ilo.org/global/ About the_ILO/Mission_and_objectives/lang--en/index.htm (last visited Aug. 9, 2010); ILO, Origins and History, http://www.ilo.org/global/About_the_ILO/Origins_and_history/lang--en/index.htm (last visited Aug. 9, 2010).

25 ILO Declaration on Fundamental Principles and Rights at Work, art. 2, http://www.ilo.org/declaration/thedeclaration/textdeclaration/lang--en/index.htm (last visited Aug. 9, 2010); see also Freedom of Association and Protection of the Right to Organise Convention, ILO C87, http://www.ilo.org/ilolex/cgi-lex/convde.pl?C087 (last visited Aug. 9, 2010); Right to Organise and Collective Bargaining Convention, (ILO C98 1949), http://www.ilo.org/ilolex/cgi-lex/convde.pl?C098 (last visited Aug. 9, 2010). 
nized the significance of this gateway when, in 1941, only six years after the NLRA's passage, the Court upheld the Board's interpretation of employee to include job applicants. Writing for the Court, Justice Frankfurter stated:

Discrimination against union labor in the hiring of [workers] is a dam to self-organization at the source of supply. The effect of such discrimination is not confined to the actual denial of employment; it inevitably operates against the whole idea of the legitimacy of organization. In a word, it undermines the principle which . . . is recognized as basic to the attainment of industrial peace. ${ }^{27}$

Defining the statutory term employee then is significant because, as the Supreme Court has pointed out, those rights belong "only to those workers who qualify as 'employees' as that term is defined in the Act" and only those employees are entitled to the Act's protection. ${ }^{28}$ This is so, notwithstanding the fact that all workers would benefit from more fully protected freedom of association and more effective protection of collective-bargaining rights from government and private interference, restraint, and coercion. ${ }^{29}$ And this is so, notwithstanding the belief of many dignitaries of the international community "that universal and lasting peace can be accomplished only if it is based on social justice.",30

I have argued in a separate article that work law should be grounded in the values of autonomy and dignity. ${ }^{31}$ Those foundational principles, I argue, generate a role for the law to safeguard what I have termed the "autonomous dignified worker," by ensuring that workers are free to become part authors of their working lives (autonomy) and that workers are treated with the equality of respect afforded to them as human beings (dignity) as opposed to commodities. ${ }^{32}$ I have further argued that, to be autonomous, workplaces must satisfy the following four preconditions: the

\footnotetext{
26 Professor Ellen Dannin makes the same point in Not a Limited, Confined, or Private Matter Who Is an "Employee" Under the National Labor Relations Act, 59 LAB. L. J. 5,5 (2008).

27 Phelps Dodge Corp. v. NLRB, 313 U.S. 177, 185 (1941).

28 NLRB v. Town \& Country Elec., Inc., 516 U.S. 85, 89 (1995); see also Union Repression, supra note 13. Workers who are not considered employees under NLRA Section 2(3) not only lose federal protection of these fundamental rights, but their mere involvement in an organizing drive would be unlawful under Section 8(a)(2)'s (29 U.S.C. § 158(a)(2) (2006)) prohibition against employer interference with the administration of a labor union.

29 See generally Anne Marie Lofaso, Toward a Foundational Theory of Workers' Rights: The Autonomous Dignified Worker, 76 UMKC L. REV. 1 (2007) [hereinafter The Autonomous Dignified Worker].

30 ILO, Origins and History, http://www.ilo.org/global/About_the_ILO/Origins_and_history/ lang--en/index.htm (last visited Aug. 9, 2010).

31 See generally The Autonomous Dignified Worker, supra note 29.

32 See generally id.
} 
mental ability to identify work-life influences, accessibility to information sufficient to generate a range of workplace options, independence from coercion, and modes of participation that empower workers to effectuate changes in their working lives. ${ }^{33}$ The fourth precondition also dignifies workers by flattening the hierarchy between workers and managers. I have also shown that union representation and collective bargaining are compatible with the values underlying the autonomous dignified worker, even if they are not the only forms of industrial democracy to promote those values. $^{34}$

Assuming that I am correct in asserting an appropriate role for the law, it is my task below to determine whether the statutory definition of employee satisfies my quest for the autonomous dignified worker. To accomplish this goal, I ask the following questions:

Does that definition broadly include all workers?

If not, who is excluded and why?

Has that definition changed over time?

If so, has the definition become more or less inclusive and what rationales have been used to change the definition?

\section{Deconstructing the Statutory Definition of Employee REVEALS A DyNAMIC DEFINITION THAT HAS BEEN NARROWED}

A. The Wagner Act Board Expansively Construed the Definition of Employee Consistent with Its Plain Language

1. The NLRA Defines Employee Both Affirmatively and Negatively

Congress passed the National Labor Relations Act in 1935. At that time, Section 2(3) defined employee as follows:

The term "employee" shall include any employee, and shall not be limited to the employees of a particular employer, unless the Act explicitly states otherwise, and shall include any individual whose work has ceased as a consequence of, or in connection with, any current labor dispute or because of any unfair labor practice, and who has not obtained any other regular and substantially equivalent employment, but shall not include any individual employed as an agricultural

33 See id. at 40-42.

34 See id. at 42-48, 57-64. 
laborer, or in the domestic service of any family or person at his home, or any individual employed by his parent or spouse.

The Wagner Board, ${ }^{36}$ ultimately with Supreme Court approval, ${ }^{37}$ construed that statutory definition in a manner true to its plain meaning. The Board recognized that the statutory definition has both affirmative and negative components. ${ }^{38}$ The Act defines first who an employee is and then who an employee is not - who is exempted. In concert with accepted principles of statutory construction, the Board construed the affirmative aspect of that definition broadly as written and narrowly construed the exemptions or negative aspects.

We can express the Board's construction in the following manner. Affirmatively, the Act defined (and continues to define) employee to include "any employee" and not just those "employees of a particular employer." 40 Negatively, the Act expressly exempted (and still exempts) agricultural workers, domestic servants, and certain family members - the children and spouses of employers, in particular. Using "EE" to symbolize the term "employee," "ER" to symbolize employers, "AW" to symbolize agricultural workers, "DS" to symbolize domestic servants, and "FAM" to

3529 U.S.C. $\$ 152(3)(1935)$.

36 I use the term "Wagner Board" to refer to the early boards between 1935 and 1947.

37 See NLRB v. Hearst Publ'ns, Inc., 322 U.S. 111 (1994) (holding that newsboys were employees under the NLRA, despite contentions that they are independent contractors and should be excepted); Packard Motor Car Co. v. NLRB, 330 U.S. 485, 487-91 (1947) (holding that minor foremen, who were responsible for quantity and quality production control in a mass-production industry, were employees under the NLRA, notwithstanding contentions that these workers were either employers within the meaning of the NLRA or so closely aligned with the employer's interests that it was undesirable to consider them statutory employees).

38 See Phelps Dodge Corp. v. NLRB, 313 U.S. 177, 191 (1941) (recognizing that the Act defines employee "both affirmatively and negatively").

39 See, e.g., Holly Farms Corp. v. NLRB, 517 U.S. 392, 399 (1996) (explaining that the agricultural exemption to the NLRA's statutory definition of employee is to be narrowly construed); NLRB v. Hendricks County Rural Elec. Membership Corp., 454 U.S. 170, 186-89 (1981) (approving the Board's narrow construction of the confidential employee exception); see also David Wolcott Kendall Mem'l Sch. v. NLRB, 866 F.2d 157, 160 (6th Cir. 1989) (explaining that the managerial exception "must be narrowly construed to avoid conflict with the broad language of the Act, which covers 'any employee,' including professional employees"); Ankh Servs., 243 N.L.R.B. 478, 480 \& n.17 (1979) (noting that Congress intended only to exclude "domestic servants" from the "in the domestic service of any family or person at his home" exemption); see also NLRB v. Imperial House Condo., Inc., 831 F.2d 999, 1005 (11th Cir. 1987) (holding that housekeepers working for a condominium association are not exempted from the NLRA's coverage because they are not domestic servants within the meaning of NLRA Section 2(3)); Mercy Hosp. of Buffalo v. NLRB, 668 F.2d 661, 666 n.2 (1982) (noting the narrowness of the family exception and further noting that "courts have refused automatically to exclude a principal shareholder's child or spouse under section 2(3)") (citing Linn Gear Co. v. NLRB, 608 F.2d 791, 795 (9th Cir. 1979)).

$40 \quad 29$ U.S.C. § 152(3) (2006). 
symbolize the employer's spouse and children, we can schematize the original definition of employee in the following way:

$$
\mathrm{EE}=[\text { any } \mathrm{EE}+\sim(\mathrm{EEs} \text { of a particular ER })+\text { strikers }]-[\mathrm{AW}+\mathrm{DS}+\mathrm{FAM}]
$$

\section{The Affirmative Aspect of the Statutory Definition of Employee Broadly Includes All Employees Unless Otherwise Exempted}

The Supreme Court has ultimately approved of the Board's basic construction of the statutory definition of employee as "striking[ly]" broad. But that construction evolved over several years of the NLRA's life. From the start, the Board, with the approval of reviewing courts, breathed meaning into the statutory definition simply by noticing that the affirmative part of the definition's plain language was in fact broadly written to include "any employee" and "shall not be limited to the employees of a particular employer." "The plain language thus supported the Board's view that the "statutory definition is of wide comprehension."

But the Board still had to overcome the potentially circular nature of the definition. ${ }^{44}$ To do this, the Board interpreted the broad statutory language - "[t]he term 'employee' shall include any employee"45 - to mean "all employees in the conventional as well as legal sense except those by

41 Sure-Tan, Inc. v. NLRB, 467 U.S. 883, 891-92 (1984). In fact, the Supreme Court repeatedly approved the early Board's broad construction of the affirmative aspect of NLRA Section 2(3), 29 U.S.C. 152(3). See, e.g., NLRB v. E.C. Atkins \& Co., 331 U.S. 398, 404-12 (1947) (private plant guards, who are required to be civilian auxiliaries to the U.S. Army's military police); NLRB v. Jones \& Laughlin Steel Corp., 331 U.S. 416, 422 (1947) (deputized plant guards); Phelps Dodge Corp., 313 U.S. at 191-92 (1941) (job applicants); NLRB v. Mackay Radio \& Tel. Co., 304 U.S. 333, 345 (1938) (unfair labor practice and economic strikers).

42 The Supreme Court ultimately upheld the Board's view that Section 2(3)'s broad language, which expressly refuses to "limit[]" the statutory term employee " to the employees of a particular employer" was "intended to protect employees when they engage in otherwise proper concerted activities in support of employees of employers other than their own." Eastex, Inc. v. NLRB, 437 U.S. 556 (1978) (quoting 29 U.S.C. § 152(3)) (holding that employees seeking to improve the working conditions of less privileged workers of other employers are protected in that activity).

43 Atl. Greyhound Corp., 7 N.L.R.B. 1189, 1196 (1938) (so stating in the context of rejecting the argument that managers and supervisors are not statutory employees because the Board repeatedly relies on evidence of the antiunion conduct of such workers as proof that the employer has engaged in unfair labor practices); see also Hearst Publ'ns, Inc., 9 N.L.R.B. 1262, 1274 (1938) (reaffirming the "wide scope" of the statutory definition).

44 See Marley Weiss, Kentucky River at the Intersection of Professional and Supervisory Status Fertile Delta or Bermuda Triangle?, in LABOR LAW STORIES 353, 356 (Lara J. Cooper \& Catherine L. Fisk eds., 2005), available at http://digitalcommons.law.umaryland.edu/fac_pubs/124/ ("[T]he § 2(3) definition of 'employee' was either extremely broad or else vague, and was, in any event, circular.").

4529 U.S.C. $\$ 152(3)(1935)$. 
express provision excluded." 46 The Board concluded that the "primary consideration" in determining whether a worker is a statutory employee was "whether effectuation of the declared policy and purposes of the Act comprehends securing to the individual the rights guaranteed and protection afforded by the Act." The Board then expounded a "[p]ublic interest in the administration of the Act [that] permits an inquiry into the material facts and substance of the [employer-worker] relationship." to assess, on a case-by-case basis, whether including the challenged worker within the statutory framework effectuated the policies of the Act.

As a result of the inductive-part of this approach, the Board, in facing early challenges to worker status, concluded that all types of workers were statutory employees. For example, the Board repeatedly concluded that strikers who had ceased working because of a labor dispute, ${ }^{48}$ minor supervisors, ${ }^{49}$ and drivers who might ordinarily be classified as independent contractors, ${ }^{50}$ among others, were statutory employees.

The Board's fact-based analysis closely followed the Act's plainlanguage imperatives, where applicable. For example, in the case of strikers, the Board pointed out that the statutory definition made clear that "any individual whose work has ceased as a consequence of, or in connection with, any current labor dispute or because of any unfair labor practice, and who has not obtained any other regular and substantially equivalent employment" was a statutory employee. Accordingly, once the Board, with Supreme Court approval, established that strikers were expressly

46 Hearst Publ'ns, Inc., 9 N.L.R.B. at 1274 (examining the definition of employee in the context of employment contracts purporting to establish the worker's status as other than employee); Olympia Shingle Co., 26 N.L.R.B. 1398, 1413 (1940).

47 Hearst Publ'ns, Inc., 9 N.L.R.B. at 1275; accord Olympia Shingle Co., 26 N.L.R.B. at 1413 nn.11-12.

48 NLRB v. Mackay Radio \& Tel. Co., 304 U.S. 333, 345 (1938); Phelps Dodge Corp., 19 N.L.R.B. 547, 565-66 nn.20-23 (1940), enforced as modified, Phelps Dodge Corp. v. NLRB, 113 F.2d 202 (2d Cir. 1940), remanded, 313 U.S. 177 (1941); Lone Star Gas Co., 18 N.L.R.B. 420,458 n. 51 (1939); Mooresville Cotton Mills, 2 N.L.R.B. 952, 956 (1937), enforced on these grounds, Mooresville Cotton Mills v. NLRB, 94 F.2d 61 (4th Cir. 1938); Carlisle Lumber Co., 2 N.L.R.B. 248, 262 (1936); $c f$. NLRB v. Fansteel Metallurgical Corp., 306 U.S. 240, 255-58 (1939) (concluding that the NLRB does not have unlimited authority to order reinstatement of Section 2(3) employee-strikers where those strikers have otherwise engaged in dischargeable misconduct); Columbian Enameling \& Stamping Co., 1 N.L.R.B. 181, 194-95 (1935), enforcement denied on other grounds, NLRB v. Columbian Enameling \& Stamping Co., 96 F.2d 948 (7th Cir. 1938), aff'd, 306 U.S. 292, 296-300 (1939) (recognizing that strikers are statutory employees but affirming court's denial of enforcement of Board's bargaining order on grounds that substantial evidenced did not support Board's view that union request bargaining at an appropriate time).

49 Atl. Greyhound Corp., 7 N.L.R.B. 1189, 1196 (1938) (holding that bus terminal dispatcher is a statutory employee even though his duties could be described as supervisory).

50 Hearst Publ'ns, Inc., 9 N.L.R.B. at 1275

5129 U.S.C. § 152(3) (1935). 
included in the statutory definition, the employee-striker cases focused not on whether such workers were employees but instead on the question whether the employee had "obtained any other regular and substantially equivalent employment," as the statute's plain language expressly required.

But in most cases, the Board simply focused on its policy of finding employee status by resorting to the "conventional" meaning of that term and whether finding a particular worker to be a statutory employee effectuated the NLRA's policies and purposes:

In cases where the status of an individual was challenged, we have indicated that the statutory definition of the term "employee" embraces all employees in the conventional as well as legal sense, except those by express provision excluded and that the primary consideration in the determination of the applicability of the statutory definition is whether effectuation of the declared policy and purposes of the Act comprehend securing to the individual the rights guaranteed and protection afforded by the Act. ${ }^{52}$

Using that test, the Board approached the question whether a worker was a statutory employee not on the basis of whether the worker could possibly be classified as something other than an employee, but simply on the basis of whether that worker met the broad, conventional definition of employee. Accordingly, rather than disqualifying minor supervisors or minor stockholding workers simply because those workers could also be characterized as "employers," the Board reasonably found that the following workers were covered by the NLRA simply because they met the statutory definition of employee: unskilled lumber stackers and their foreman; ${ }^{53}$ newspaper district managers, who perform all the same work as the assistants under their supervision; ${ }^{54}$ and stockholding workers. ${ }^{55}$ And rather than disqualifying other workers who could be classified as independent contractors under common law, the Board reasonably found that the following workers were statutory employees, again, simply because they met the statutory definition of employee: contract employees, ${ }^{56}$ truck drivers

\footnotetext{
Stockholders Publ'g Co., 28 N.L.R.B. 1006, 1022-24 n.33 (1941).

James E. Stark Co., 33 N.L.R.B. 1076, 1080-81 (1941).

Hearst Publ'ns, Inc., 25 N.L.R.B. 621, 628-29 (1940).

Olympia Shingle Co., 26 N.L.R.B. 1398, 1413-14 (1940).

Connor Lumber \& Land Co., 11 N.L.R.B. 776, $786-87$ (1939).
} 
who owned only one truck, ${ }^{57}$ newspaper motor route drivers, ${ }^{58}$ newspaper delivery carriers, ${ }^{59}$ and newspaper delivery boys. ${ }^{60}$

3. The Negative Aspect of the Statutory Definition of Employee Must Be Narrowly Construed

When Congress originally enacted the NLRA there were only three statutory exemptions to the definition of employee: agricultural workers, domestic servants, and the spouses or children of employers. ${ }^{61}$ The Wagner Board narrowly construed those exemptions. The Supreme Court has also ultimately vindicated the Board's approach: "administrators and reviewing courts must take care to assure that exemptions from NLRA coverage are not so expansively interpreted as to deny protection to workers the Act was designed to reach." ${ }^{62}$ And reviewing courts have ultimately vindicated the approach of narrowly circumscribing the three original exemptions.

The Wagner Board's narrow constructions of those three exemptions are still in use today. The Wagner Board analyzed the express statutory exemptions - again by resorting to the common understanding of those statutory terms. In one early case, for example, the Board relied on the common understanding of the term "agricultural" to narrowly construe the agricultural exemption so as not to include workers who performed the services of processing, canning, packing, marketing, and shipping mushrooms. ${ }^{63}$ In another early case, the Board concluded that machine-shop workers who maintained and repaired agricultural equipment also were not agricultural workers - and noted that its interpretation was consistent both with common usage of the term agricultural and with the construction of that term as used in other employment statutes. ${ }^{64}$

The Eleventh Circuit, the only court of appeals to review the Board's interpretation of the domestic servant exclusion, has twice upheld the Board's narrow construction of that exemption. ${ }^{65}$ In both cases, the court

57 Murphy Timber Co., 37 N.L.R.B. 487, 491-92 n.5 (1941).

58 Hearst Publ'ns, Inc., 9 N.L.R.B. 1262, 1274-75 (1938).

59 See, e.g., Constitution Publ'g Co., 29 N.L.R.B. 105, 112 (1941); Park Floral Co., 19 N.L.R.B. 403, 415 (1940); Hearst Publ'ns, Inc., 9 N.L.R.B. at 1275.

60 Stockholders Publ'g Co., 28 N.L.R.B. 1006, 1022-24 n.33 (1941).

6129 U.S.C. $\$ 2(3)(1935)$.

62 Holly Farms Corp. v. NLRB, 517 U.S. 392, 399 (1996).

63 Great W. Mushroom Co., 27 N.L.R.B. 352, 359 nn.9-11 (1940).

64 E. Clemens Horst, Co., 23 N.L.R.B. 1193, 1199-1202 nn.7-14 (1940); see also Park Floral Co., 19 N.L.R.B. at 413-14 nn.24-26 (finding that greenhouse workers, including growers and assistant growers, were not, among other things, agricultural workers within the meaning of the Act and therefore were statutory employees entitled to the Act's protections).

65 See Shore Club Condo. Ass'n, Inc. v. NLRB, 400 F.3d 1336, 1338-40 (11th Cir. 2005) (maintenance and cleaning employees who work for the owners of individual home units within a condominium 
rejected the employer's attempt to expand the exclusion to maintenance workers and housekeepers of condominium units.

The family exemption is expressly limited to the parent or spouse of a covered employer. ${ }^{66}$ Although later Boards have interpreted the family exemption to include the parent or spouse of a majority shareholder in a closely held corporation, ${ }^{67}$ reviewing courts have chastised the Board for attempting to expand that exemption beyond the plain language. ${ }^{68}$ The Board will however review on a case-by-case basis whether other close family workers, who are statutory employees, should be excluded from bargaining units under Section 9(b) of the Act. This distinction is significant. Although such close relatives might be appropriately excluded from a particular bargaining unit because the family member's interests are more closely aligned with management's than with those of the bargaining unit members, ${ }^{69}$ these family-employees still retain the statutory rights of workers to band together for mutual aid or protection or in other concerted activity. $^{70}$ Accordingly, the family-employer cannot, for example, discharge them or otherwise discriminate against them because of their concerted activity.

and in the common areas of that condominium are not domestic services within the meaning of NLRA Section 2(3)); NLRB v. Imperial House Condo., Inc., 831 F.2d 999, 1005 (11th Cir. 1987) (holding that housekeepers working for a condominium association are not exempted from the NLRA's coverage because they are not domestic servants within the meaning of NLRA Section 2(3)); Ankh Servs., 243 N.L.R.B. 478, 480 \& n.17 (1979) (noting that Congress intended only to exclude "domestic servants" from the "in the domestic service of any family or person at his home" exemption).

6629 U.S.C. § 2(3) (2006); see also Mercy Hosp. of Buffalo v. NLRB, 668 F.2d 661, 666 n.2 (1982) (noting the narrowness of the family exception and further noting that "courts have refused automatically to exclude a principal shareholder's child or spouse under section 2(3)") (citing Linn Gear Co. v. NLRB, 608 F.2d 791, 795 (9th Cir. 1979)); Butchers Union, Local No. 120, Amalgamated Meat Cutters \& Butcher Workmen, 160 N.L.R.B. 1465, 1468 n.3 (1966).

67 Cerni Motor Sales, 201 N.L.R.B. 918,918 (1973).

68 See, e.g., NLRB v. Caravelle Wood Prods., Inc., 466 F.2d 675, 678 (7th Cir. 1972) (rejecting the Board's Foam Rubber City formulation for determining the children/spouse exception as being too "elastic").

69 The Board does not automatically exclude family workers on the basis of that relationship; nor does the Board exclude such family workers from bargaining units "absent evidence that because of such relationship [the family worker] enjoys a special status which allies his interests with those of management." Atlanta Daily World, 179 N.L.R.B. 999, 1007 (1969) (quoting Int'l Metal Prods. Co., 107 N.LR.B. 65, 67 (1953)) (holding that section 2(3)'s family exemption did not extend to the nephews of general manager and editor of daily newspaper and that the nephews should not be excluded from the bargaining unit because the evidence failed to show that the nephews lacked a community of interest with the other bargaining unit employees"); see also Allen Servs. Co., 314 N.L.R.B. 1060, 1062 \& n.9 (1994)

70 See, e.g., Caravelle Wood Prods., Inc., 466 F.2d at 678-79 (discussing this issue). 
B. The Wagner Board's Broad Construction of the Plain-Language Definition of Employee Coupled with the Wagner Board's Narrow Construction of the Limited Exemptions to that Definition Paved the Way for the Taft-Hartley Statutory Amendments

\section{The Wagner Board, With Supreme Court Approval, Concluded that the Wagner Act Protected Minor Foremen and Independent Contractors}

Reviewing courts ultimately concluded that the Board's broad interpretation of the statutory term employee and narrow construction of the three main statutory exemptions were reasonable and thus generally upheld those interpretations and the Board's application of its reasonable interpretation of the law to the facts of the particular case. But employers continued to challenge these interpretations, which tended to benefit workers by bringing more rather than fewer of them under the NLRA's protective cover.

Employers were particularly concerned about union infiltration among foremen. ${ }^{71}$ The blossoming of union membership during the Wagner era, which resulted in collective bargaining agreements with improved wages and other terms and conditions of employment, also led to discontent among front-line supervisors, whose status and economic position began to deteriorate compared with those they supervised." This "led in the early 1940's to large-scale unionization by manufacturing foremen." 74

Employers were threatened by this large-scale unionization among manufacturing foremen. According to labor scholar Professor Marley Weiss, in the employer's view:

[U]nionization threatened to shift the allegiance of foremen to the working class, depriving employers of loyal front-line agents and potentially impairing operational efficiency. Manufacturing firms depended on their foremen to enforce discipline and productivity in harsh, unsafe, repetitive assembly line jobs. Union-based loyalty to the interests of the workers could subvert the supervisor's enforcement of policies aimed at extracting increased productivity and discipline.

71 See Weiss, supra note 44, at 355-59.

72 Professor Weiss reports that "[u]nion membership quintupled from three million to fifteen million between 1935 and 1947." See id. at 356 (citing sources). Among the sources cited therein, see generally DAVID BRODY, WORKERS IN INDUSTRIAL AMERICA: ESSAYS ON THE TWENTIETH CENTURY STRUGGLE 157 (2d ed. 1993).

73 See Weiss, supra note 44, at 356.

74 See id. 
Unionized foremen also might strike with the rank and file, or honor their picket lines. ${ }^{75}$

Employers viewed unionization among foremen as a shift in loyalty from the ruling to the ruled class, which, in their view, directly harmed employer interests in productivity.

Employer dissatisfaction with the Board's interpretation of the statutory definition culminated in two cases: Packard Motor Car Co. v. $N L R B$, where the Supreme Court upheld the Board's conclusion that the statutory definition broadly included minor foreman, ${ }^{76}$ and NLRB v. Hearst Publications, where the Court upheld the Board conclusion that the statutory definition broadly included independent contractors. ${ }^{77}$

In Packard Motor Car, the Supreme Court held that the Board reasonably concluded that foremen as a class of workers are statutory employees who may self-organize and band together for the purposes of collective bargaining or mutual aid and protection. ${ }^{78}$ The Court drew that conclusion in the context of deciding whether the company's minor supervisory personnel - the general foremen, foremen, assistant foremen, and special assignment men - were statutory employees. ${ }^{79}$ These 1,100 minor foremen were themselves supervised and controlled by the company's managers, which included an additional thirteen rungs above the general foremen.

In reaching its conclusion, the Court rejected the company's two main contentions as being "at odds with [the NLRA's] plain terms." of statutory construction, the Court rejected the company's contention that these minor foremen were not statutory employees because they met the statutory definition of employer, which "includes any person acting in the interest of the employer. ${ }^{, 82}$ The Court answered that the company's contention proved too much because "[e]very employee, from the very fact of employment in the master's business, is required to act in his interest. He owes to the employer faithful performance of service in his interest, the protection of the employer's property in his custody or control, and all employees may, as to third parties, act in the interests of the employer to such an extent that he is liable for their wrongful acts."

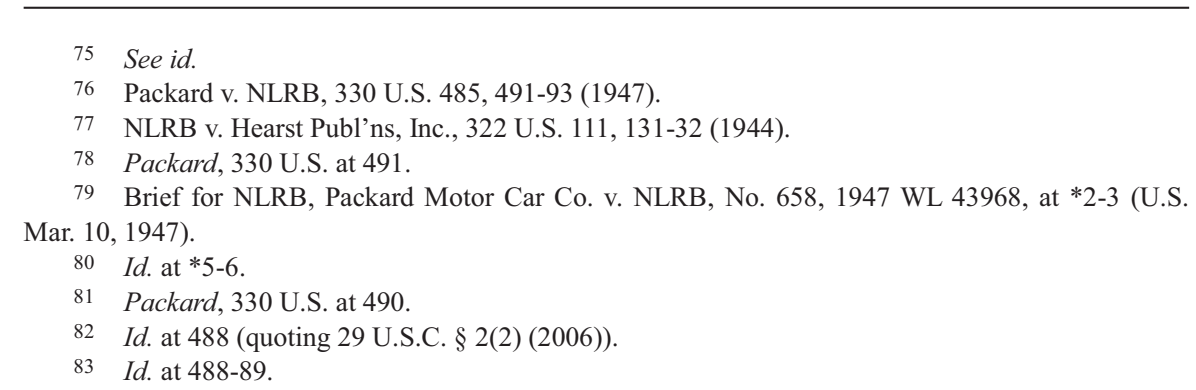


The Court also rejected what it viewed to be the company's central concern - "the undesirability of permitting foremen to organize" who might "combine to bargain advantages for themselves, [and] will sometimes be governed by interests of their own or of their fellow foremen, rather than by the company's interests." ${ }^{84}$ The Court dismissed the company's argument as "rooted in the misconception that because the employer has the right to wholehearted loyalty in the performance of the contract of employment, the employee does not have the right to protect his independent and adverse interest in the terms of the contract itself and the conditions of work."

The Court also dismissed the company's argument that permitting foremen to unionize is "bad industrial policy ... [because] it puts the union foreman in the position of serving two masters, divides his loyalty and makes generally for bad relations between management and labor." ${ }^{, 86}$ The Court explained that it was not its function to rule on "the wisdom of the legislation," implicitly inviting Congress to act if it disagreed with the Board's reasonable statutory construction.

In Hearst, the Supreme Court upheld the Board's finding that newsboys are "employees" of the newspapers employing them, entitling the newsboys to the NLRA's protection. ${ }^{87}$ In finding that only the full-time fixed-spot newsboys and checkmen were statutory employees, the Board drew a line contrasting those workers with "bootjackers" - other workers who sell at varying times in varying places. ${ }^{88}$ Particularly relevant to the Board's decision was the amount of control that the employer exercised over the full-time newsboys and checkmen: the full-time newsboys stationed at fixed spots were under direct and close supervision of a district manager, who fixed the newsboy's main selling spot, unilaterally controlled the number of papers the newsboy was required to take each day, effectively fixed the newsboys' compensation, and prescribed the broad terms and conditions of the newsboys' day in a number of ways. ${ }^{89}$

The Court rejected, as inconsistent with creating uniform, national labor policy, the newspaper's argument that the newsboys were independent

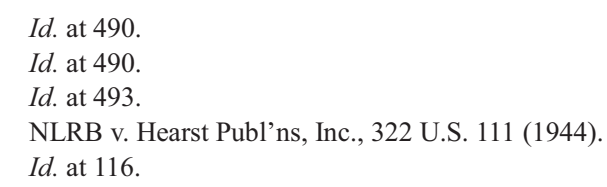

89 Id. at 116-18. The district managers could order the transfer of newsboys from one spot to another for disciplinary reasons, district managers may set hours of work and adherence to the hours is observed by supervisory agents of Hearst, sanction might be ordered to those that are tardy or delinquent. In addition, district managers gave "helpful sales techniques" that the newsboys were expected to follow, such as how to display the newspaper, which headlines to emphasize, where to place advertisements, among others. Id. at 118-19. 
contractors within the common law meaning of that term and therefore that they should be excluded from the NLRA's statutory definition of employee. $^{90}$ The Court explained that adopting a common law approach would lead to a "patchwork plan for securing freedom of employees' organization and of collective bargaining" because the definition of independent contractor and employee were not uniform in either rule or application, as the company's fallaciously approach assumed. ${ }^{91}$

It would introduce variations into the statute's operation as wide as the differences the forty-eight states and other local jurisdictions make in applying the distinction for wholly different purposes. Persons who might be 'employees' in one state would be 'independent contractors' in another. They would be within or without the statute's protection depending not on whether their situation falls factually within the ambit Congress had in mind, but upon the accidents of the location of their work and the attitude of the particular local jurisdiction in casting doubtful cases one way or the other. Persons working across state lines might fall in one class or the other, possibly both, depending on whether the Board and the courts would be required to give effect to the law of one state or of the adjoining one, or to that of each in relation to the portion of the work done within its borders. ${ }^{92}$

Simply put, the newspaper's approach was inconsistent with Congress's intention "to solve a national problem on a national scale."

The Court also rejected the newspaper's argument that independent contractors should be exempted from the statutory definition of employee on grounds that such a narrow construction of the statutory term employee was inconsistent with "the history, terms and purpose of the legislation." In the Court's view, "Congress . . . was not thinking solely of the immediate technical relation of employer and employee" when drafting the NLRA.

It had in mind at least some other persons than those standing in the proximate legal relation of employee to the particular employer involved in the labor dispute. It cannot be taken, however, that the purpose was to include all other persons who may perform service for another or was to ignore entirely legal classifications made for other purposes. Congress had in mind a wider field than the narrow tech-

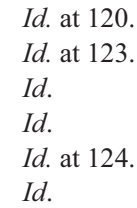


nical legal relation of 'master and servant,' as the common law had worked this out in all its variations, and at the same time a narrower one than the entire area of rendering service to others. The question comes down therefore to how much was included of the intermediate region between what is clearly and unequivocally 'employment,' by any appropriate test, and what is as clearly entrepreneurial enterprise and not employment. ${ }^{96}$

By concluding that it would uphold the Board findings if its determinations "ha[ve] warrant in the record and a reasonable basis in law," the Court once again implicitly invited Congress to amend the NLRA if it disagreed with the Board's reasonable construction of the statutory terms. ${ }^{97}$

2. The Pre-Taft-Hartley Debate Over Who Qualifies As an Employee Essentially Is a Fight Over Whether to Maintain the Hierarchical Organization of Post-War Industry and a Rigid LaborManagement Binary

Some members of Congress were outraged about Supreme Court decisional law that affirmed the Board's view that minor supervisory personnel and independent contractors were statutory employees who possessed Section 7 rights. ${ }^{98}$ Those congressional members wanted to "deprive[] the Board of jurisdiction over [those categories of workers]." history suggests several reasons for removing the Board's jurisdiction over these workers.

The House Report gave three reasons for removing foremen and other supervisory personnel from the NLRA - all consistent with a world view that believes in a labor-management binary and that the loyalty of minor supervisory personnel is necessary to maximize productivity in the manufacturing-industrial economic sector. The Report explained that unionizing supervisory personnel (1) "would be bad for output, which the act was intended to promote," (2) "bad for the rank and file," and (3) "bad for the foremen themselves." 100 The House Report supported its first contention -

96 Id. at $124-25$.

97 Id. at 131. This deference that the Court shows to the Board in interpreting the Act is later understood and articulated as Chevron deference.

98 Disclaimer: The legislative history recounted here is not meant to support any particular construction of the Taft-Hartley amendments. Rather, this history merely helps create a context for better understanding the passionately held views of those management advocates who felt that the Wagner Act was a cure for labor-management imbalance worse than the disease.

99 H.R. REP. No. 245, at 304 (1947), reprinted in 1 NLRB, LEGISLATIVE HiSTORY OF THE LABOR MANAGEMENT RELATIONS ACT, 1947, at 304 (1948).

100 Id. 
that "unionizing supervisors . . . is inconsistent with the purpose of the act to increase output of goods that move in the stream of commerce, and thus to increase its flow" productivity declined after the foremen organized [at the Ford Motor Co. in November 1942]." "102 By contrast, the report dismissed with no discussion the "claim[]" of the foreman association's president that "productivity was high in plants that it had organized."103

The House Report's remaining two contentions appear to be heavily grounded in the class-based ideology ${ }^{104}$ that all workers fall into the labormanagement binary and that any good unions might do can be done only in support of the rank and file. Indeed, the Report's use of the term "rank and file" itself suggests the bifurcation of the workplace into subordinates and leaders. Along these lines, the House Report supported its second contention - that unionizing supervisors is bad for the rank and file - on grounds that "[i]t is inconsistent with the policy of Congress to assure to workers freedom from domination or control by their supervisors in their organizing or bargaining activities." 105 But the Report fails to explain how unionizing supervisors is inconsistent with that policy, stating only that the two policies are "inconsistent."

On the flip side, the House Report supported its third contention - that unionizing supervisors is bad for the foremen themselves - on two grounds. First, embedded in the House Report, in a manner reminiscent of Plato's gold, silver, and bronze people, ${ }^{106}$ is a stark class-based argument for why unionization is bad for foremen:

Supervisors are management people. They have distinguished themselves in their work. They have demonstrated their ability to take care of themselves without depending upon the pressure of collective action. No one forced them to become supervisors. They abandoned

101 Id. at 305, reprinted in 1 NLRB, Legislative History OF THE LABOR MANAgEMENT RELATIONS ACT 1947, at 305 (1948).

102 Id.

103 Id.

104 Marion Crain and Ken Matheny make a similar point in "Labor's Divided Ranks": Privilege and the United Front Ideology, 84 CORNELL L. REV. 1542 (1998-99).

105 H.R. REP. NO. 245, at 305 (1947), reprinted in 1 NLRB, LEGISLATIVE HistORY OF THE LABOR MANAGEMENT RELATIONS ACT, 1947, at 305 (1948).

106 Plato, The Republic, Book III 177-80 (Benjamin Jowett trans., The Heritage Press 1944) (arguing that the ideal state comprises three classes: rulers or guardians (those with gold souls), warriors (those with silver souls), and the people, who were farmers and craftsmen (those with bronze souls)). Plato's system is not a binary but a tripartition. Nevertheless, the analogy holds for all the reasons presented in this paper. As explained infra, under the Taft-Hartley philosophy, supervisors (silver people) must be exempted from the NLRA because managers (those who represent the interests of the gold people) are entitled to the loyalty of certain workers. 
the "collective security" of the rank and file voluntarily, because they believed the opportunities thus opened to them to be more valuable to them than such "security." It seems wrong, and it is wrong, to subject people of this kind, who have demonstrated their initiative, their ambition and their ability to get ahead, to the leveling processes of seniority, uniformity and standardization that the Supreme Court recognizes as being fundamental principles of unionism. ... It is wrong for the foremen, for it discourages the things in them that made them foremen in the first place. For the same reason, that it discourages those best qualified to get ahead, it is wrong for industry, and particularly for the future strength and productivity of our country.

The preceding excerpt shows that the Report doesn't even bother to hide this class ideology, which assumes that union members are interested in "the leveling processes of seniority, uniformity and standardization," "108 at the expense of excluding rewards for workers' achievement. In the view of the Report's drafters, "it is wrong[] to subject" supervisors and foremen "people of this kind, who have demonstrated their initiative, their ambition and their ability to get ahead" - to the union's leveling process. ${ }^{109}$ It is "wrong" to subject supervisors or foremen - even low-level supervisors to the possibility of unionism because unionism "discourages the things in them that made them foremen in the first place."110 The Report leaps from that conclusion to the following one: for the same reasons that unionism "discourages those best qualified to get ahead, it is wrong for industry, and particularly for the future strength and productivity of our country."

This part of the House Report reveals the fundamental values reflected in a capitalist-based economy: a world view that highly values competition as the best method for promoting productivity and a world view that believes in the existence of the meritocracy. Even if promoting these values actually achieves productivity and meritocracy (a statement I take issue with), the threshold fallacies with this argument are that those selected to be supervisors are inherently more worthy, that unionism inevitably results in leveling, and that leveling is bad in all cases. The ideology underlying the Report then is fundamentally inconsistent with a workplace policy that dignifies workers or promotes their autonomy. ${ }^{112}$

107 H.R. REP. No. 245, at 307-08 (1947), reprinted in 1 NLRB, LEGISLATIVE HiSTORY OF THE Labor Management Relations ACt, 1947, at 307-08 (1948).

108 Id.

109 Id.

$110 \mathrm{Id}$.

111 Id.

112 See generally The Autonomous Dignified Worker, supra note 29. 
The House Report also argues that unionizing foremen is bad for foremen because it is bad for employers. This argument conflates what is good for foremen with what is good for the employer, an argument that echoes the employer's fallacy-embedded protestations in Packard Motor that foremen were not statutory employees because they were employers. The Report explains that unionizing foremen "is inconsistent with our policy to protect the rights of employers." The Report then particularizes that right: "employers . . . are entitled to loyal representatives in the plants." "113 It explains that employers need their supervisors to be autonomous or independent from rank-and-file workers, "but when . . . foremen unionize, even in a union that claims to be 'independent' of the union of the rank and file, they are subject to influence and control by the rank and file union, and, instead of their bossing the rank and file, the rank and file bosses them." "114

There also appears to be a fourth reason for removing foremen from the Board's jurisdiction - fear of unionization itself and the consolidation of power among the working class. In particular, the Report expresses concern with the growth of unionization among foremen and the implications of that growth. The purpose of the Labor Act "was to protect workers and their unions against foremen, not to unionize foremen.", "In few trades, and in none of the great mass-producing industries, were foremen unionized. It was not until about [seven] years after Congress passed the Labor Act that anyone asked the Labor Board to establish a unit composed of supervisors." "116 The Report also expresses concern about the implication of such growth in foremen unions:

The committee received in evidence about 200 letters that the Foreman's Association had exchanged with unions of the rank and file. They showed a closer and more intimate relation between the association and the unions of men the foremen supervise than one ordinarily finds between unions affiliated together in the same federation, and a

113 H.R. ReP. No. 245, at 305, reprinted in 1 NLRB, Legislative History of the LABOR MANAGEMENT RELATIONS ACT, 1947, at 305 (1948).

114 Id.

115 Id. at 304, reprinted in 1 NLRB, LEgISLATIVE HiSTORY OF THE LABOR MANAGEMENT RELATIONS ACT, 1947, at 304 (1948); see also Weiss, supra note 44, at 355-59.

116 H.R. REP. No. 245, at 305, reprinted in 1 NLRB, LEGISLATIVE History OF THE LABOR Management Relations Act 1947, at 304 (1948) (citing Md. Drydock Co., 49 N.L.R.B. 733, 737 (1943)). 
subservience of the association of unions of the rank and file that is rare among unions. ${ }^{117}$

Accordingly, unionization among foremen must be stopped because it results in ruling class subservience to the working class.

The Senate Report supports its contention that unionizing supervisors is bad for employers and bad for workers by arguing that when supervisors are unionized they are less likely to do their job of disciplining the workforce and keeping the workers safe:

The folly of permitting a continuation of this policy is dramatically illustrated by what has happened in the captive mines of the Jones \& Laughlin Steel Corp. since supervisory employees were organized by the United Mine Workers under the protection of the act. Disciplinary slips issued by the underground supervisors in these mines have fallen off by two-thirds and the accident rate in each mine has doubled. ${ }^{118}$

In the views of these committee members, supervisory unionization was causally linked to lax discipline and decreased safety - a variation on the subservience and productivity arguments.

Reading the House and Senate rationales together suggests that some members of Congress were concerned with establishing a "balance" between labor and management. Although that balance may be upset when workers (bronze people) have no means for expressing themselves and therefore they are entitled to organize and protect themselves from the excesses of management coercion symptomatic of an industrialized society (Wagner philosophy), that balance is also upset when management itself (in this case, silver people) ${ }^{119}$ organizes (Taft-Hartley philosophy). The explanation for this argument is two-fold. First, when supervisors or managers unionize, they exacerbate rather than restore the balance of power between rank and file and management by tipping the balance too much in favor of the working class through class consolidation. Second, when supervisors unionize they harm business both by decreasing productivity and by identifying with the wrong class of workers - the rank and file - rather than with the employer's business interests. "If management is to be free to manage American industry as in the past and to produce the goods on which

117 Id. at 306, reprinted in 1 NLRB, Legislative History OF THE LABOR MANAGEMENT RELATIONS ACT, 1947, at 306 (1948).

118 S. REP. NO. 105, at 4 (1947), reprinted in 1 NLRB, LEGisLATIVE History OF THE LABOR MANAGEMENT RELATIONS ACT, 1947, at 410 (1948).

119 Some managers, such as Chief Executive Officers and other high-level officials may very well be gold people. I am concerned here, not with those who make policy, but the silver soldiers who implement policy. This article does not attempt to figure how to draw that line. 
depends our strength in war and our standard of living always," the Report concludes that:

Congress must exclude foremen from the operation of the Labor Act, not only when they organize into unions of the rank and file and into unions affiliated with those of the rank and file, but also when they organize into unions that claim to be independent of the unions of the rank and file. ${ }^{120}$

Unlike the supervisory exemption's legislative history, the independent contractor exemption's history does not attempt to rationalize the line between the protected statutory employee and unprotected independent contractor. Rather, the legislative record suggests that some members of Congress believed that there was a natural line between those two classes of workers and that the Board, the Supreme Court, or both acted arbitrarily in disregarding those categories. Indeed, immediately prior to attacking the Board's construction of the statutory definition of employee, the Report sarcastically characterizes that construction as dimwitted: “An 'employee', according to all standard dictionaries, according to the law as the courts have stated it, and according to the understanding of almost everyone, with the exception of members of the National Labor Relations Board, means someone who works for another for hire.",121

The assumption - that the definitions of employee and independent contractor were patently obvious (a bad assumption, in my view) - freed Congress to focus its attack on the Board for giving (and the Court for endorsing) "far-fetched meanings" to plain words with "ordinary meanings," such as independent contractor. ${ }^{122}$ The House Report viewed its mission as "correct[ing] what the Board has done, and what the Supreme Court, putting misplaced reliance upon the Board's expertness, has approved." $" 123$ That Report proceeds not so much to analyze where particular Board decisions actually assert jurisdiction too broadly over the wrong classes of workers but rather to question the Board's rationality. In particular, given the Board's alleged inability to discern the "natural" demarcation

120 H.R. REP. NO. 245, at 306 (1947), reprinted in 1 NLRB, LEGISLATIVE HistORY OF THE LABOR MANAGEMENT RELATIONS ACT, 1947, at 306 (1948) (emphasis added).

121 The Report further explains that line as follows: There is and always has been a "big difference" between employees, who "work for wages or salary under direct supervision," and independent contractors, who "undertake to do a job for a price, decide how the work will be done, usually hire others to do the work, and depend for their income not upon wages, but upon the difference between what they pay for goods, materials, and labor and what they receive for the end result, that is, upon profits." Id. at 309 (1947), reprinted in 1 NLRB, LEGISLATIVE HISTORY OF THE LABOR MANAGEMENT RELATIONS ACT, 1947, at 309 (1948).

122 Id.

123 Id. 
between employee and independent contractor, the Report focuses instead on the need to remedy the excessive deference afforded to the Board's analysis of this question.

It is inconceivable that Congress, when it passed the act, authorized the Board to give to every word in the act whatever meaning it wished. $^{124}$

There has been some dissatisfaction with what has been viewed as too great a tendency on the part of the courts not to disturb Board findings, even though they may be based on questions of mixed law and fact. $^{125}$

In many instances, deference on the part of the courts to specialized knowledge that is supposed to inhere in administrative agencies has led the courts to acquiesce in decisions of the Board even when the findings concerned mixed issues of law and fact. ${ }^{126}$

The Senate Report was similarly concerned with the rejection of the common law test for distinguishing between employees and independent contractors:

[T] he Supreme Court has . . . held that the ordinary tests of the law of agency could be disregarded by the Board in determining if petty occupational groups were "employees" within the meaning of the Labor Relations Act. The Court consequently refused to consider the question whether certain categories of persons whom the Board had deemed to be "employees" might not, as a matter of law, have been independent contractors. The legal effect of the amendment therefore is merely to make it clear that the question whether or not a person is an employee is always a question of law, since the term is not meant to embrace persons outside that category under the general principles of the law of agency. ${ }^{127}$

The Senate Report thus envisions a tightly constrained Board, tethered by law to distinguish between independent contractor and employee status along "natural" lines. What the Report does not seem to anticipate is that

124 Id.

125 Id. at 432, reprinted in 1 NLRB, Legislative History of THE LABOR MANAGEMENT RELATIONS ACT, 1947, at 432 (1948) (citing among others NLRB v. Hearst Publ'ns, Inc., 322 U.S. 111 (1944)).

126 Id. at 559-60, reprinted in 1 NLRB, LEgislative History OF THE LABOR MANAGEMENT RELATIONS ACT, 1947, at 559-60 (1948) (citing among others Hearst Publ'ns, Inc., 322 U.S. 111).

127 Congressional Record, Senate (June 5, 1947), reprinted in 2 NLRB, Legislative History of the Labor Management Relations ACt 1947, at 1537 (1948) (citing Hearst Publ'ns, Inc., 322 U.S. 111). 
the common law agency test is so elastic that the question whether a particular worker is a statutory employee or independent contractor will remain largely within the Board's discretion.

C. The Taft-Hartley Statutory Amendments Maintained the Affirmative Definition of Employee but Broadened that Definition's Statutory Exemptions To Exclude Supervisors and Independent Contractors

1. For Over a Half Century, the Board, with Court Approval, Continued to Broadly Construe the Affirmative Aspect of the Statutory Definition

In 1947, Congress, over President Truman's veto, amended NLRA Section 2(3) in response to Packard Motor Car Company and Hearst Publications. The affirmative aspect of the definition remained unchanged.

And the Board, with court approval, has continued to construe the affirmative aspect of the definition broadly in concert with the plain language. Indeed, the coming years witnessed the broadest construction of the affirmative aspect of the statutory definition to date. In the 1960s, the Supreme Court twice affirmed the status of strikers as statutory employees. $^{128}$ In 1978, in Eastex, Inc. v. NLRB, the Supreme Court upheld the Board's view that well-paid employees engaged in the Section 7 protected activity of distributing pro-minimum-wage literature at the jobsite were statutory employees because the plain language of Section 2(3) expressly declares that employees "shall not be limited to the employees of a particular employer.", "129 In 1984, in Sure-Tan, Inc. v. NLRB, the Supreme Court held that the striking breadth of Section 2(3) squarely covered undocumented workers. ${ }^{130}$ In 1995, in NLRB v. Town \& Country Electric, Inc., the Supreme Court, by unanimous decision, upheld the Board's reasonable conclusion that paid union organizers, or salts, were statutory employees. ${ }^{131}$ When coupling that conclusion with the long-held conclusion that job applicants also are statutory employees, ${ }^{132}$ reviewing courts have upheld the Board's determination that an employer may not discriminate in the hiring of qualified workers who inform the employer that they intend to lawfully

128 NLRB v. Fleetwood Trailer Co., 389 U.S. 375 (1967); NLRB v. Erie Resistor Corp., 373 U.S. 221 (1963) ("[Section] 2(3) preserves to strikers their unfilled positions and status as employees during the pendency of a strike.").

129 Eastex, Inc. v. NLRB, 437 U.S. 556 (1978) (quoting 29 U.S.C. § 152(3) (2006)). In light of the facts of this case, which expressly protects workers as a class to protect other members of the working class, I have dubbed it the "comrades-of-the-world-unite-case."

130 Sure-Tan, Inc. v. NLRB, 467 U.S. 883 (1984).

131516 U.S. 85, 98 (1995).

132 Phelps Dodge Corp. v. NLRB, 313 U.S. 177, 191-92 (1941). 
unionize that employer's workforce. The only limit to the affirmative aspect of the statutory definition came in 1971, when, in Chemical Workers v. Pittsburgh Plate Glass Co., the Supreme Court held that retired persons were not statutory employees because they literally do not "work for another for hire." 133

It is now uncontroversial that the Board, not the Courts, have the primary task of determining "the contours of the term "employee." "134 It is also long-settled that, when undertaking this task, the Board uniformly interprets the term "employee" in the "broad generic sense" to "include members of the working class generally." "135 And every Board, until the Bush II Board, continued to apply this expansive interpretation of the affirmative aspect of Section 2(3) with court approval.

2. Notwithstanding Supreme Court Approval of a Broadly Construed Affirmative Definition of Employee, the Bush II Board Reversed Course and Restricted the Definition By Reading Certain Classes of Employees - Salts, Students and the Severely Disabled - Out of the NLRA's Protective Cover ${ }^{136}$

Notwithstanding the long-standing, court-approved precedent broadly construing the affirmative aspects of the plain language of NLRA Section 2(3), the Bush II Board chose to read several subclasses of employees out of the NLRA and created a new test for reading out many more workers. As a threshold matter, the Bush II Board proclaimed that, despite the nearuniversal breadth of the plain statutory language, it "ha[d] the discretion to determine whether it would effectuate national labor policy to extend collective-bargaining rights to [a particular] category of employees," and that

133 Chem. Workers v. Pittsburgh Plate Glass, 404 U.S. 157, 168 (1971).

134 Id. at 167; see also NLRB v. Town \& Country Elec., Inc., 516 U.S. 85, 89-90 (1995); Holly Farms Corp. v. NLRB, 517 U.S. 392, 398-99 (1996); Sure-Tan, Inc. v. NLRB, 467 U.S. 883, 891 (1984); Bayside Enterprises, Inc. v. NLRB, 429 U.S. 298, 304 (1977); NLRB v. Hearst Publ'ns, Inc., 322 U.S. 111, 130 (1944); Local No. 207, Int'l Ass'n of Bridge Workers v. Perko, 373 U.S. 701, 706 (1963); NLRB v. E.C. Atkins \& Co., 331 U.S. 398, 403-04 (1947).

135 Briggs Mfg. Co., 75 N.L.R.B. 569, 570 (1947); Little Rock Crate \& Basket Co., 227 N.L.R.B. 1406, 1406 (1977); Oak Apparel, Inc., 218 N.L.R.B. 701, 707 (1975); L.D. Brinkman Se., 261 N.L.R.B. 204, 210 (1984); see also W.D.D.W. Commercial Sys. \& Invs., Inc., 335 N.L.R.B. 260, 269 n.3 (2001). Indeed, the Supreme Court itself recognized the class-based definition of employee as early as 1941 when it wrote: "the reference is to 'employees', unqualified and undifferentiated. To circumscribe the general class, 'employees', we must find authority either in the policy of the Act or in some specific delimiting provision of it.” Phelps Dodge Corp. v. NLRB, 313 U.S. 177, 191 (1941).

136 Portions of the discussion in this section were taken from and originally published in two of my recent articles: The Persistence of Union Repression in an Era of Recognition; and September Massacre: The Latest Battle in the War on Workers' Rights Under the National Labor Relations Act. See generally Union Repression, supra note 13; September Massacre, supra note 13. 
it was "not compelled to include [that category of employees] in a bargaining unit if the Board determines it would not effectuate the purposes and policies of the Act to do so." 137 Applying that rationale, the Bush II Board declined to exercise authority over several subclasses of employees, most notably salts, ${ }^{138}$ graduate teaching or research assistants, ${ }^{139}$ and severely disabled workers.

In the most recent case, Toering Electric Co., the Bush II Board held that salts (i.e., paid union organizers who seek employment with an employer for the purpose of organizing that employer's workforce) ${ }^{141}$ are not statutory employees in circumstances where the salt does not intend to accept a job if offered. ${ }^{142}$ The Bush II Board based its decision on several arguments that fly in the face of both Supreme Court precedent and other case precedent. As an initial matter, the Bush II Board, mischaracterizing Supreme Court precedent that discusses the NLRA's strikingly broad definition of employee, ${ }^{143}$ asserted that it need not "extend[] the protections of statutory employees to all other workers who are not specifically excluded" "from the statute's definition. The Bush II Board then cited its own relatively recent cases to justify its argument that such a broad definition of employee would be contrary to precedent, ignoring the fact that more longstanding precedent from previous Boards would dictate a different result.

After narrowly interpreting Phelps Dodge Corp. v. NLRB - a Supreme Court case famously (and broadly) holding that job applicants are treated as statutory employees under the Act $^{146}$ - the Bush II Board questioned whether "job applicants who lack a genuine interest in seeking an employ-

137 Brown Univ., 342 N.L.R.B. 483, 492 (2004) (emphasis added).

138 Toering Elec. Co., 351 N.L.R.B. 225 (2007).

139 Brown Univ., 342 N.L.R.B. at 483.

140 Brevard Achievement Ctr., Inc., 342 N.L.R.B. 982, 982 (2004).

141 Some believe that the term salt "may be derived from the phrase 'salting a mine,' which is the artificial introduction of metal or ore into a mine by subterfuge to create the false impression that the material was naturally occurring." Tualatin Elec., Inc. v. NLRB, 84 F.3d 1202, 1203 n.1 (9th Cir. 1996). See also Victor J. Van Bourg \& Ellyn Moscowitz, Salting the Mines: The Legal and Political Implications of Placing Paid Union Organizers in the Employer's Workplace, 16 HoFSTRA LAB. \& EMP. L.J. 1, 5 (1998).

142 Toering Elec. Co., 351 N.L.R.B. at 225.

143 See, e.g., Sure-Tan, Inc. v. NLRB, 467 U.S. 883, 891 (1984) ("The breadth of [Section] 2(3)'s definition is striking: the Act squarely applies to 'any employee."”); NLRB v. Town \& Country Elec., Inc., 516 U.S. 85, 91 (1995) (upholding the Board's "broad, literal interpretation" of Section 2(3) as consistent with the NLRA's plain language, its statutory purposes, and interpretative case law).

144 Toering Elec. Co., 351 N.L.R.B. at 228.

145 Id. (citing Brevard Achievement Ctr., Inc., 342 N.L.R.B. 982 (2004); Brown Univ., 342 N.L.R.B. 483, 488 (2004)). The Board also cites a Clinton Board decision, WBAI Pacifica Foundation, 328 N.L.R.B. 1273, 1274-75 (1999), a case easily distinguishable as involving unpaid staff positions.

146 Phelps Dodge Corp. v. NLRB, 313 U.S. 177, 185 (1941). 
ment relationship are not [statutory] employees."147 The Bush II Board held that "an applicant for employment entitled to protection as a Section 2(3) employee is someone genuinely interested in seeking to establish an employment relationship with the employer," and that "the General Counsel bears the ultimate burden of proving an individual's genuine interest in seeking to establish an employment relationship with the employer."148 The Bush II Board thereby circumvented the Supreme Court cases Phelps Dodge Corp. and NLRB v. Town \& Country Electric, Inc. ${ }^{149}$ by creating an unpersuasive distinction between job applicants who genuinely seek an employment relationship with an employer and those who do not.

The Bush II Board based its holding on several dubious factors. First, with little discussion of the NLRA's purposes or its legislative history, it viewed a "relationship between an employer and a putative job applicant who has no genuine interest in working for that employer" as not having "the economic relationship contemplated and protected by the Act."150 Ignoring its own question - whether such individuals are statutory employees - the Board then rested its conclusion on its remedial authority, arguing that statutory policies against "windfall and punitive backpay awards" supported its holding. ${ }^{151}$

The Board next mischaracterized the role of salts as those who seek only to provoke unfair labor practices by applying to employers who are hostile to unionization. Using that mischaracterization, the Board, citing Jefferson Standard - a Supreme Court case holding that employees engaged in disloyal product disparagement lose the NLRA's protection ${ }^{152}$ - declared salts disloyal because their "conduct manifests a fundamental conflict of interests $a b$ initio between the employer's interest in doing business and the applicant's interest in disrupting or eliminating this business." ${ }^{\text {, }}$ "As my colleague Professor Bob Bastress remarked to me, that quote speaks volumes about the Bush II Board's attitude toward unions. No rational union, whose interests are in maintaining and increasing job opportunities for its members, is out to "eliminat[e] business."

The Bush II Board then tried to bolster its argument when it explained that denying the NLRA's protection to workers involved in these litigation-

147 Toering Elec. Co., 351 N.L.R.B. at 229.

148 Id. at 228 (emphasis added).

149516 U.S. 85, 92, 96-98 (1995) (unanimously upholding the Board's interpretation of NLRA Section 2(3) as including paid union organizers).

150 Toering Elec. Co., 351 N.L.R.B. at 228.

151 Id. at 229.

152 NLRB v. Local Union No. 1229, Int'l Bhd. of Elec. Workers (Jefferson Standard), 346 U.S. 464, 472 (1953).

153 Toering Elec. Co., 351 N.L.R.B. at 231. 
based salting campaigns was consistent with Town \& Country Electric, the Supreme Court case that expressly rejected the argument that salts are inherently disloyal. ${ }^{154}$ The Court explained:

[The Company] argues that, when the paid union organizer serves the union . . . the organizer is acting adversely to the company. . . Thus, it concludes, the worker must be the servant (i.e., the "employee") of the union alone. ... [That] argument fails . . . because . . it lacks sufficient support in common law. The Restatement's hornbook rule (to which the quoted commentary is appended) says that a "person may be the servant of two masters . . . at one time as to one act, if the service to one does not involve abandonment of the service to the other."

It is noteworthy that the Bush II Board essentially disenfranchised salts in the face of the Supreme Court's unanimous holding in Town \& Country Electric and circuit precedent unanimously upholding backpay awards to salts. ${ }^{156}$

The Bush II Board's willingness to read a certain subclass of employees out of the NLRA's protection was part of an administrative trend toward restricting worker access to the NLRA's fundamental protections by narrowing the statutory definition of employee. For example, the Bush II Board held that teaching and research assistants at private universities are students and therefore are not statutory employees. ${ }^{157}$ The Bush II Board also held that "severely disabled" employees working as janitors are not statutory employees because their employment was primarily rehabilitative rather than economic. ${ }^{158}$

154 Town \& Country Elec., Inc., 516 U.S. at 92-98 (upholding the Board's interpretation of NLRA Section 2(3) as including paid union organizers).

155 Id. at 93-95 (quoting ReSTATEMENT (SECOND) OF AGENCY § 226 (1957) (emphasis in the original)).

156 NLRB v. Ferguson Elec. Co., 242 F.3d 426, 436 (2d Cir. 2001) (quoting Phelps Dodge Corp. v. NLRB, 313 U.S. 177, 185 (1941)); see also Tualatin Elec., Inc. v. NLRB, 253 F.3d 714 (D.C. Cir. 2001) (upholding backpay award to salt); Aneco Inc. v. NLRB, 285 F.3d 326 (4th Cir. 2002) (upholding backpay award to salt but cutting back on the amount of that award).

157 Brown Univ., 342 N.L.R.B. 483, 483 (2004). For a powerful discussion of just how destructive the Brown decision is, see Ellen Dannin, Understanding How Employees' Rights To Organize Under the National Labor Relations Act Have Been Limited: The Case of Brown University, AM. Const. Soc'Y FOR L. \& POL. (2008), http://www.acslaw.org/files/Dannin\%20Issue\%20Brief.pdf. To be fair, for the past several decades, the Board has oscillated on the question whether graduate and teaching assistants are statutory employees. But the discussion was limited to those student workers. The Bush II Board has broadened the discussion.

158 Brevard Achievement Ctr., Inc., 342 N.L.R.B. 982, 982 (2004). 
It is also significant that the Bush II Board chose to exclude employees by category rather than on a case-by-case basis. ${ }^{159}$ The Bush II Board readily admits that its decision in Brown University was based on policy. But rather than identifying even a single labor policy that its decision effectuated, the Board elaborates on a nonlabor policy: "[D]eclining to extend collective-bargaining rights to students who perform services at their educational institutions, that are directly related to their educational program" is based on the "simple and straightforward" distinction between workers who are "primarily ... students" and those who are "primarily . . . employees." "160 Based on that distinction, the Board injected the following test into the statutory definition of employee: Whether the relationship between the worker and the employer is "predominantly . . . economic in nature.", This test is applied in each of the three cases of categorical exclusion: (1) graduate teaching assistants are primarily students, not workers in a predominantly economic relationship with an employer; (2) disabled workers are not employees to the extent that they are in a primarily rehabilitative, rather than economic, relationship with their employer; and (3) salts are not statutory employees to the extent that they do not intend to create an economic relationship with their employer.

With that test, the Bush II Board categorically excludes these three worker classifications. But that test - only those whose relationship is predominantly economic in nature are protected when they organize for mutual aid or protection - strikes a decisive blow at the core of class consciousness. If the supervisory and independent contractor exemptions were the first and second blows, then this is the third-wave strike at dividing the working class.

The Bush II Board's construction of the statutory term employee - one that injects as a condition of statutory protection the intent (or capacity) to create a predominantly economic relationship with an employer - is not a reasonable construction of NLRA Section 2(3). To paraphrase the Court in Office Employees International Union, Local No. 11 v. NLRB - where it struck down the Board's categorical exclusion of a subcategory of union employers under NLRA Section 2(2) - such an "arbitrary blanket exclusion of employe[e]s as a class is beyond the power of the Board." "162 As with the Board's interpretation of the statutory term employer, not only is the Bush II Board's construction of the statutory term employee contrary to the

159 See Dannin, supra note 157 (discussing the lack of authority for this action).

160 Brown Univ., 342 N.L.R.B. at 489 (quoting St. Clare's Hosp., 229 N.L.R.B. 1000,1002 (1977)).

161 Id. at 489; accord Brevard Achievement Ctr., Inc., 342 N.L.R.B. at 984.

162 Office Employees Int'1 Union, Local No. 11 v. NLRB, 353 U.S. 313, 318 (1957). 
broad definition that includes all employees except those that are expressly exempted, but that narrow statutory construction also allows the Board to renounce jurisdiction over an entire category of employees, all of whom are important segments of American work life.

But even assuming that the NLRA's broad statutory definition does not pose a legal obstacle to the Bush II Board's test, it remains difficult to imagine what labor policy is actually effectuated by that test. Narrowing the definition of employee - by requiring employees to intend only (or at least primarily) to create an economic relationship with their employers does not promote collective bargaining between those nonemployeeworkers and their employers. Nor does it do anything to equalize bargaining power between those nonemployee-workers and their employers. Nor does the Bush II Board explain why nonemployee-workers, such as students and disabled workers (both of whom are particularly vulnerable and powerless), are less entitled to claim the fundamental rights embodied in Section 7. Nor has the Board explained how narrowing the definition of employee promotes industrial peace.

Rather, the Bush II Board's test examines the question of statutoryemployee status from the employer's vantage point: will the employer economically benefit from this relationship? Ignoring the fact that employers always benefit economically from the labor output of their workers, the Bush II Board proceeds to explain that if the answer to its question is no either because the worker is primarily a student, or a disabled worker whom the employer is helping to rehabilitate, or the worker intends to organize the employer's workplace - then those workers are not employees for purposes of a statute intended to promote the fundamental right of workers to selforganize for the purposes of collective bargaining and mutual aid or protection.

On the flip side, the Bush II Board's analysis discounts the economic value of the relationship to the nonemployee-worker. For example, graduate teaching assistants accept those work assignments not merely because they might learn something from the job but also because they are typically paid for performing those jobs, which also may be bundled with tuition waivers or other things of economic value. To say that all graduate teaching or research assistants are therefore disenfranchised from their Section 7 right to band together for mutual aid or protection merely because they are "primarily" students - and therefore have not created a relationship that is primarily economic in nature - hinges the worker's right to organize and band together for mutual aid or protection on the employer's interest. That

163 Id. at 318. 
construction of the NLRA, rather than promoting the values underlining the Act, eviscerates them. ${ }^{164}$

3. The Board's and the Court's Construction of the Two New Statutory Exemptions under Taft-Hartley

\section{a. Overview of the New Statutory Exemptions}

Through the Taft-Hartley amendments, Congress also expanded the negative aspect of the definition to include:

- any individual employed as an agricultural laborer, or

- any individual . . . in the domestic service of any family or person at his home, or

- any individual employed by his parent or spouse, or

- any individual having the status of an independent contractor, or

- any individual employed as a supervisor, or

- any individual employed by an employer subject to the Railway Labor Act. . ., or

- any individual employed . . . by any other person who is not a [statutory] employer. ${ }^{16}$

Using "EE" to symbolize the term, "employee," "ER" to symbolize employers, "AW" to symbolize agricultural workers, "DS" to symbolize domestic servants, "FAM" to symbolize the employer's spouse and children, "IC" to symbolize independent contractor, "SUP" to symbolize supervisor, "RLA" to symbolize workers covered under the Railway Labor Act, and "GOV" to symbolize those who work for a person who is not a statutory employer (typically government employees), we can schematize the original definition of employee in the following way:

164 For a further discussion of how the Bush II Board further weakened the NLRA's protective cover of salts and undocumented workers by "cut[ting] off the remedy, just in case there [wa]s any right remaining," see The Autonomous Dignified Worker, supra note 29, at 61; Union Repression, supra note 13, at 213-14 (analyzing the extent that labor law currently protects salts in light of Bush II Board decisions Toering Electric and Oil Capitol and discussing the curtailment of remedies for undocumented workers after Hoffman Plastics); September Massacre, supra note 13; and see also Ellen Dannin, Hoffman Plastics as Labor Law - Equality at Last for Immigrant Workers?, 44 U. SAN FRAN. L. REV. 393 (2010).

16529 U.S.C. $\S 152(3)(2006)$. 
$\mathrm{EE}=\left[\right.$ any $\mathrm{EE}+{ }^{\sim}($ EEs of a particular ER $)+$ strikers $]-[\mathrm{AW}+\mathrm{DS}+\mathrm{FAM}+$ $\mathrm{IC}+\mathrm{SUP}+\mathrm{RLA}+\mathrm{GOV}]$

The Railway Labor Act and public employees are generally protected under other labor legislation. Accordingly, we can reschematize our definition as follows:

$\mathrm{EE}=[$ any $\mathrm{EE}+\sim($ EEs of a particular ER $)+$ strikers $]-[\mathrm{AW}+\mathrm{DS}+\mathrm{FAM}+$ $\mathrm{IC}+\mathrm{SUP}]$

At issue here are the final two categorical exemptions: independent contractors and supervisors.

b. The Board and the Court Apply Principles of Agency Law to Construe the Statutory Term, Independent Contractor

Those favoring the independent contractor exemption may have won the battle but not necessarily the war, which, for reasons explained below, has resulted in a stalemate. ${ }^{166}$ It is now well-settled that the Board and reviewing courts must apply the common-law agency test for determining whether a worker should be classified as an employee or as an independent contractor. $^{167}$ The Board, with court approval, ${ }^{168}$ relies primarily on the following multifactor analysis of the Restatement (Second) of Agency Law:

(1) A servant is a person employed to perform services in the affairs of another and who with respect to the physical conduct in the performance of the services is subject to the other's control or right to control.

(2) In determining whether one acting for another is a servant or an independent contractor, the following matters of fact, among others, are considered:

(a) the extent of control which, by the agreement, the master may exercise over the details of the work;

(b) whether or not the one employed is engaged in a distinct occupation or business;

(c) the kind of occupation, with reference to whether, in the locality, the work is usually done under the direction of the employer or by a specialist without supervision;

166 See supra text accompanying notes 258-59.

167 NLRB v. United Ins. Co., 390 U.S. 254, 256 (1968); FedEx Home Delivery v. NLRB, 563 F.3d 492, 495-96 (D.C. Cir. 2009).

168 See, e.g., FedEx Home Delivery, 563 F.3d at 497-99. 
(d) the skill required in the particular occupation;

(e) whether the employer or the workman supplies the instrumentalities, tools, and the place of work for the person doing the work;

(f) the length of time for which the person is employed;

(g) the method of payment, whether by the time or by the job;

(h) whether or not the work is a part of the regular business of the employer;

(i) whether or not the parties believe they are creating the relation of master and servant; and

(j) whether the principal is or is not in business. ${ }^{169}$

The Board has held that it has "no authority to change" that test, as it normally does when interpreting the ambiguous language in the NLRA. ${ }^{170}$ But that does not mean that distinguishing between that statutory employee and independent contractor is an easy one to resolve. Nor does it mean that the Board's role as fact finder is insignificant in making that determination. Supreme Court decisional law instructs that the Restatement's nonexhaustive, ten-factor test is not easy to apply: "there is no shorthand formula or magic phrase that can be applied to find the answer, but all of the incidents of the relationship must be assessed and weighed with no one factor being decisive." $" 171$

Other courts have elaborated on the difficulty in applying the common law test, which after all:

is not merely quantitative. We do not just count the factors that favor one camp, and those the other, and declare that whichever side scores the most points wins. Instead, there also is a qualitative assessment to evaluate which factors are determinative in a particular case, and why. ... [T] his qualitative evaluation "focus[es] not upon the employ-

169 Restatement (SECOND) OF AGENCY $§ 220$ (1958). The Board has not passed on the question whether the Restatement (Third) of Agency has any affect on the legal test that it must apply. See RESTATEMENT (THIRD) OF AGENCY $§ 7.07$ (2006) (defining employees acting with the scope of employment for purposes of subjecting employer to vicarious liability for a tort committed by that employee); see also Reporter's Note, cmt. a (stating that "[t]his section is a consolidated treatment of topics covered in several separate sections of Restatement, Second, Agency, including . . § 220"). This question, however, is largely academic because the Restatement (Third) of Agency does not appear to make any real change in the ten-factor test, the purpose of which is to distinguish a servant, the performance of whose services "is subject to the other's control or right of control" with an independent contractor. Compare RESTATEMENT (SECOND) OF AGENCY § 220(1) (1958) (defining servant), with $\S 220(2)$ (1958) (defining independent contractor).

170 St. Joseph News Press, 345 N.L.R.B. 474, 478 (2005).

171 United Ins. Co., 390 U.S. at 258. 
er's control of the means and manner of the work but instead upon whether the putative independent contractors have a 'significant entrepreneurial opportunity for gain or loss." "172

Such a fact-intensive test, which allows the Board to assess the "total factual context . . . in light of the pertinent common-law agency principles" ${ }^{\prime 173}$ gives sufficient, if not palatial, space for the Board (whose findings of fact are entitled to deference so long as substantial evidence on the record as a whole supports them ${ }^{174}$ ) to reasonably support its conclusion one way or the other. The Supreme Court in NLRB v. United Insurance Company clarified the point - that the Board's factual findings are entitled to deference under the Universal Camera's substantial evidence test - in the context of affirming the Board's view that certain insurance agents were statutory employees, not independent contractors. Notwithstanding reviewing courts' superior expertise in deciding common law questions, the Court recognized those courts' (and its own) limited authority over the Board in stating that, even in this context, a reviewing court may not "displace the Board's choice between two fairly conflicting views, even though the court would justifiably have made a different choice had the matter been before it de novo." 175

The vastness of this fact-gathering space is demonstrated in the twin cases of Roadway Package System, Inc. ${ }^{176}$ and Dial-A-Mattress. ${ }^{177}$ Both cases dealt with the question whether certain delivery truck drivers are statutory employees or independent contractors. Both cases applied the common-law agency test for determining the distinction between a statutory employee and independent contractor under the NLRA. But in cases decided on the same day, the Clinton Board held that the Roadway drivers

172 FedEx Home Delivery, 563 F.3d at 497 n.3.

173 United Ins. Co., 390 U.S. at 258.

17429 U.S.C. $\$ 160($ e) (2006); Universal Camera Corp. v. NLRB, 340 U.S. 474, 488 (1951).

175 United Ins. Co., 390 U.S. at 260 (quoting Universal Camera Corp., 340 U.S. at 488 (internal quotation marks omitted)). In NLRB v. United Insurance Co., the Court based its affirmation of the Board's finding that the insurance agents were statutory employees on the following decisive factors: The agents "do not operate their own independent businesses, but rather perform functions that are an essential part of the company's normal operations; they need not have any prior training or experience, but are trained by company supervisory personnel; they do business in the company's name with considerable assistance and guidance from the company and its management personnel and ordinarily sell only the company's policies;" they operate under the Company's unilaterally promulgated and controlled "'Agent's Commission Plan;"” they "account to the company for the funds they collect under an elaborate and regular reporting procedure;" they receive benefits (vacation, group insurance and pension plan); and they "have a permanent working arrangement with the company under which they may continue so long as their performance is satisfactory." Id. at 259.

176 Roadway Package Sys., 326 N.L.R.B. 842 (1998).

177 Dial-A-Mattress, 326 N.L.R.B. 884 (1998). 
were statutory employees but the Dial-A-Mattress drivers were independent contractors.

As a threshold matter, both cases clarified the Board's analysis for determining independent contractor status. In particular, relying on Supreme Court decisional law, the Board in Roadway clarified that, "in determining the distinction between an employee and an independent contractor under Section 2(3) . . . [it would] apply the [Restatement's] common-law agency test and consider all the incidents of the individual's relationship to the employing entity." while the common-law test "ultimately assesses the amount or degree of control exercised by an employing entity over an individual," it would consider all factors in determining "whether or not there is a sufficient group of favorable factors to establish the employee relationship." "179

Not only is no one factor decisive, but the same set of factors that was decisive in one case may be unpersuasive when balanced against a different set of opposing factors. And though the same factor may be present in different cases, it may be entitled to unequal weight in each because the factual background leads to an analysis that makes that factor more meaningful in one case than in the other. ${ }^{18}$

Application of these principles in the two lead cases, Roadway Package System and Dial-A-Mattress, produced opposite results. In Roadway Package System, the Board held that the drivers for a nationwide smallpackage pickup and delivery system were statutory employees because those drivers - who did business in Roadway's name, drove uniformly marked, custom-designed vehicles custom produced to Roadway's specifications, and wore Roadway approved uniforms - did not operate their own independent businesses and did not ordinarily engage in outside business, but instead performed functions that were an essential and integral part of the company's normal operations and under its substantial control. To this end, these drivers did not need prior training or experience, but received training from the company and had no substantial proprietary interest be-

178 Roadway, 326 N.L.R.B. at 850; see id. at 849-50 (citing United Ins. Co., 390 U.S. at 256-58; Cmty. for Creative Non-Violence v. Reid, 490 U.S. 730, 752 (1989); Nationwide Mut. Ins. Co. v. Darden, 503 U.S. 318, 324 (1992)). In each of the cases cited, the Supreme Court used the common-law test to distinguish between "employee" and "independent contractor" under various federal statutes. See Darden, 503 U.S. at 323 (Employee Retirement Income Security Act of 1974); Reid, 490 U.S. at 739-40 (Copyright Act of 1976); United Ins. Co., 390 U.S. at 256 (NLRA); see also NLRB v. Town \& Country Elec., 516 U.S. 85, 92-94 (1995) (making that observation).

179 Roadway, 326 N.L.R.B. at 850 (quoting RESTATEMENT (SECOND) OF AGENCY § 220(1) (1958), cmt. c).

180 Roadway, 326 N.L.R.B. at 850 (quoting Austin Tupler Trucking, 261 N.L.R.B. 183, 184 (1982)) 
yond the investment in their trucks. There was no significant entrepreneurial opportunity for gain or loss resulting in large part from company imposed obstacles. In particular, although the drivers had a contractual right to use their vehicles for non-company business so long as they masked the company's conspicuous logo on the vehicle, no driver had done so because they were prohibited from conducting other commercial business during the business day and had other company commitments that ran into the evening, making other commercial activity difficult to pursue. ${ }^{181}$

By contrast, in Dial-A-Mattress, the Board held that the company's owner-operator-drivers, who provided customer delivery services, were independent contractors under the common law test, primarily because there were less obstacles for entrepreneurial gain or loss. Compensation was based on delivery with no guaranteed minimum. Owner-operators were not prohibited from making additional money by performing additional work for customers in exchange for separate payment and were otherwise allowed to use their vehicles for compensated deliveries for anyone other than a Dial-A-Mattress competitor. Moreover, the owner-operators had a distinct identity and independence from the company. In particular, the owner-operators typically owned more than one truck, which were not of uniform model, make, color, or size and which displayed the logo of the owner-operators' company, not that of Dial-A-Mattress. The owneroperators hired their own assistants to help with loading or even driving. Nor did Dial-A-Mattress control the owner-operators, who were not required to return to the company's warehouse at the end of the day and were not trained by the company. ${ }^{182}$

c. Until Recently, the Board, with Court Resistance, Had Attempted to Narrowly Construe the Term, Supervisor

A very different analysis applies to the statutory supervisory exemption. NLRA Section 2(11) defines supervisor as:

any individual having authority, in the interest of the employer, to hire, transfer, suspend, lay off, recall, promote, discharge, assign, reward, or discipline other employees, or responsibly to direct them, or to adjust their grievances, or effectively to recommend such action, if in connection with the foregoing the exercise of such authority is not of a

181 Roadway, 326 N.L.R.B. at 851-53.

182 Dial-A-Mattress, 326 NLRB at 885-89. 
merely routine or clerical nature, but requires the use of independent judgment. ${ }^{183}$

By contrast with the independent contractor exemption, where Congress has removed court deference to the Board's construction of that statutory term, the Board receives full Chevron ${ }^{184}$ deference in its interpretation of Section 2(11). ${ }^{185}$ Reviewing courts readily approved the Board's construction of Section 2(11), which is a multi-part disjunctive test embedded into a three-part conjunctive test.

The three-part conjunctive test provides the structure of Section 2(11) in the following manner. A supervisor is any worker who:

(1) possesses any one of the twelve enumerated powers or is authorized to effectively recommend such action; and

(2) exercises that authority "in the interest of the employer;" and

(3) is required to use "independent judgment" rather than judgment that is of "a merely routine or clerical nature," when exercising that authority.

This three-part test eliminates many workers from NLRA coverage. ${ }^{186}$ After all, embedded into this test is essentially a twenty-four-part disjunctive test. If a worker possesses even one of the twelve enumerated powers or can effectively recommend such action, then that worker is a supervisor ${ }^{187}$ unless that worker does not exercise such power in the interest of the employer or that worker is not required to use independent judgment when exercising such power. The in-the-interest-of-the-employer prong saves very few workers; after all, workers are expected to act in the interest of

18329 U.S.C. $\$ 152(11)(2006)$.

184 Chevron U.S.A. Inc. v. Natural Res. Def. Council, Inc., 467 U.S. 837, 842-44 (1984).

185 See, e.g., NLRB v. Ky. River Cmty. Care, Inc., 532 U.S. 706, 713-14, 721-22 (2001) (recognizing that the Board is entitled to Chevron deference but ultimately rejecting the Board's construction of the term "independent judgment" as not reasonable) (citing Chevron U.S.A. Inc., 467 U.S. at 842-44)). Prior to 1984, the Board also received considerable deference when interpreting the NLRA. I call those cases, pre-Chevron, Chevron cases.

186 See, e.g., NLRB v. Pilot Freight Carriers, Inc., 558 F.2d 205, 209-10 (4th Cir. 1977) (trucking company dispatchers who controlled work assigned to drivers); Local 28, Int'l Organization of Masters, Inc. v. NLRB, 321 F.2d 376, 377-78 (D.C. Cir. 1963) (shipmates who issued orders to deckhands, during locking and docking operations and emergency situations "which required prompt and faithful obedience for the protection of person and property" exercised independent judgment and were supervisors).

187 See, e.g., Hosp. Gen. Menonita v. NLRB, 393 F.3d 263, 267 n.5 (1st Cir. 2004); Edward Street Daycare Ctr., Inc. v. NLRB, 189 F.3d 40, 45 (1st Cir. 1999); Micro Pac. Dev. Inc. v. NLRB, 178 F.3d 1325, 1330 (D.C. Cir. 1999). 
their employer, even if otherwise motivated. ${ }^{188}$ The question whether a worker is an employee or a supervisor then often turns on whether that worker exercises independent judgment.

Notwithstanding the limitations of the statutory language on the statutory definition of employee, for decades, the Board, with court approval, was able to distinguish between "employees with minor supervisory duties," such as "straw bosses, leadmen, setup men, and other minor supervisory employees," who were not intended to be excluded from the coverage of the Act, ${ }^{189}$ and "the supervisor vested with such genuine management prerogatives as the right to hire or fire, discipline, or make effective recommendations with respect to such action." "Using this distinction as a guiding principle, the Board routinely found, mostly in the manufacturing or industrial sector but also among blue collar (as opposed to white collar) jobs, that assistant foremen, ${ }^{191}$ gang leaders, ${ }^{192}$ guard sergeants, ${ }^{193}$ dispatch and switchboard operators, ${ }^{194}$ workers who spent some fraction of their time assigning work to other workers or otherwise being in charge, ${ }^{195}$ and other

188 NLRB v. Health Care \& Ret. Corp., 511 U.S. 571, 577-78 (1994) (nurses who exercised supervisory powers in the interest of patient care meet the in-the-interest-of-the-employer prong of the supervisory test). This prong is thought not to apply to workers such as shop stewards, who might possess the supervisory power to adjust grievances, but does so in the interest of the bargaining unit rather than in the employer's interest. See id. at 579-80.

189 S. REP. No. 105, 80th Cong., 1st Sess. 4 (1947); see also, e.g., NLRB v. Quincy Steel Cast. Co., 200 F.2d 293, 296 (1st Cir. 1953) (citing SEN. REP. No. 105, 80th Cong., 1st Sess. 4 (1947)).

190 S. ReP. No. 105, 80th Cong., 1st Sess. 4 (1947).

191 NLRB v. Quincy Steel Cast. Co., 200 F.2d 293, 294 (1st Cir. 1953) (workers who spent most of their time as molders but who was acting superintendant when the superintendant was on vacation and who sporadically and infrequently assumed command position, which including the power to assign work and recommend hirings and discharges).

192 N. Va. Steel Corp. v. NLRB, 300 F.2d 168 (4th Cir. 1962) (welder who could check the work of other welders and who could make recommendations about hiring and firing but whose work was also closely supervised).

193 NLRB v. Sec. Guard Serv., Inc., 384 F.2d 143, 145-47 (5th Cir. 1967) (guards generally who checked vehicles and persons leaving through the main gate of company's establishment and patrolled the area but who also maintained a daily activity $\log$, kept time cards of the guards assigned to their shift and who relayed the captain's instructions to the other guards); NLRB v. Merchants Police, Inc., 313 F.2d 310, 312 (7th Cir. 1963) (working sergeants with greater responsibility than other guards).

194 NLRB v. City Yellow Cab Co., 344 F.2d 575(5th Cir. 1965) (taxi cab company switchboard operator, who directed cab drivers).

195 NLRB v. Don Olney Foods, Inc., 870 F.2d 1279, 1282-84 (7th Cir. 1989) (grocery store employee, who was in charge of store when manager was at lunch and every third Saturday evening ); NLRB v. Swift \& Co., 240 F.2d 65, 66-67 (9th Cir. 1957) (plant clerks who spent most of their time performing clerical tasks but who also spent some time telling other employees "where to place and when to move certain products in the course of processing," and who "take charge of the department for brief intervals when a foreman is absent" do not exercise independent judgment); Precision Fabricators, Inc. v. NLRB, 204 F.2d 567 (2d Cir. 1953) (machine worker and room boss who spent 80 percent of his time operating machines and the rest of his time assigning work to other employees did not exercise independent judgment). 
minor bosses, ${ }^{196}$ were statutory employees rather than exempted supervisors. The Board, with court approval, even found employee status in some cases where a more highly skilled or superior worker exercised control over a less capable employee. 197 In such cases, the courts found that "the employer cannot make a supervisor out of a rank and file employee simply by giving him the title and theoretical power to perform one or more of the enumerated supervisory functions." 198

\section{d. After Kentucky River, the Bush II Board Expanded the Supervisory Exemption, Thereby Punching a Gaping Hole in the Statutory Definition of Employee ${ }^{199}$}

The main impetus for the "interpretive drift" $" 200$ of the statutory definition of supervisor arose in the context of professional employees, in particular, professional employees in the healthcare industry. ${ }^{201}$ By way of back-

196 See, e.g., Highland Superstores, Inc. v. NLRB, 927 F.2d 918, 921-22 (6th Cir. 1991) (finding that leadman who merely reported facts to supervisor did not exercise authority to discipline with independent judgment); NLRB v. Harmon Indus., Inc., 565 F.2d 1047, 1049 (8th Cir. 1977) (equipment repairman and senior technician who could make work assignments, grant overtime, and transfer employees, did not exercise independent judgment); Ross Porta-Plant, Inc. v. NLRB, 404 F.2d 1180, 118182 (5th Cir. 1968) (crew leaders with no actual authority); Int'l Union of United Brewery Workers v. NLRB, 298 F.2d 297, (D.C. Cir. 1961) (driver salesmen who directed the work of their helpers); NLRB v. S. Bleachery \& Print Works, Inc.. 257 F.2d 235, 239 (4th Cir. 1958) (machine printers who checked the quality of cloth printed on the machine in their charge and who could initial time cards and material requisition slips); NLRB v. Newton Co., 236 F.2d 438, 441-42 (5th Cir. 1956) (straw bosses who performed same work as coworkers); NLRB v. Beaver Meadow Creamery, 215 F.2d 247, 251 (3d Cir. 1954) (worker who checked out eggs to driver-salesmen, kept record for bookkeeper of eggs on hand and instructed new workers in how to candle and grade eggs was at most a leadman); NLRB v. Parma Water Lifter Co., 211 F.2d 258, 261 (9th Cir. 1954) (machinist who was put in charge during supervisor's absence).

197 NLRB v. Griggs Equip., Inc., 307 F.2d 275 (5th Cir. 1962).

198 NLRB v. S. Bleachery \& Print Works, Inc., 257 F.2d 235, 239 (4th Cir. 1958)

199 Portions of the discussion in this section were taken from and originally published in two of my recent articles: The Persistence of Union Repression in an Era of Recognition; and September Massacre: The Latest Battle in the War on Workers' Rights Under the National Labor Relations Act. See generally Union Repression, supra note 13; September Massacre, supra note 13. Several labor law scholars have written about this topic. See, e.g., Ann Hodges, Lessons from the Laboratory: The Polar Opposites on the Public Sector Labor Law Spectrum, 18 Cornell J. L. \& PuB. Pol'y 735, 738-40 (2009) (comparing the breadth of the NLRA's supervisory exemption with the narrower definitions under state labor laws); Catherine L. Fisk \& Deborah C. Malamud, The NLRB in Administrative Exile: Problems with its Structure and Function and Suggestions for Reform, 58 Duke L. J. 2013, 2027 (2009); Marley S. Weiss, Kentucky River at the Intersection of Professional and Supervisory Status - Fertile Delta or Bermuda Triangle?, in LABOR LAW STORIES (Lara J. Cooper \& Catherine L. Fisk eds., 2005).

200 I am borrowing this phrase from Ellen Dannin, Not a Limited, Confined, or Private Matter Who Is an "Employee" Under the National Labor Relations Act, 59 LAB. L. J. 5, 6 (2008).

201 Several well-known labor law scholars have written about the extent to which labor law's treatment of professional workers has and will continue to shape labor law and the strength of the labor movement. See, e.g., Risa L. Lieberwitz, Faculty in the Corporate University: Professional Identity, 
ground, in Doctors' Hospital of Modesto, Inc., a case decided in 1970, the Board determined that a hospital's registered nurses were not supervisors, even though they directed other, less-skilled employees. ${ }^{202}$ In the Board's view, the nurses' "daily on-the-job duties and authority in this regard are solely a product of their highly developed professional skills and do not, without more, constitute an exercise of supervisory authority in the interest of their [e]mployer." America $(H C R)$, the Board, which was made up of predominantly Republican appointees, had no trouble applying its longstanding precedent to conclude that the nurses in that case were employees, not supervisors. ${ }^{204}$ But the Supreme Court in a 5-4 decision reversed, finding that the Board's patient-care analysis "created a false dichotomy . . . between acts taken in connection with patient care and acts taken in the interest of the employer."205

In Providence Hospital, in response to the Supreme Court's decision in $H C R$, the Clinton Board - under the leadership of Chairman William B. Gould $\mathrm{IV}^{206}$ - defined the term "independent judgment" in a manner that attempted to reconcile NLRA Section 2(11)'s exclusion of supervisors with Section 2(12)'s definition of professional employees. ${ }^{207}$ In particular, the Clinton Board explained that independent judgment does not include "ordinary professional or technical judgment in directing less skilled employees to deliver services." ${ }^{, 08}$ In NLRB v. Kentucky River Community Care, Inc., a

Law and Collective Action, 16 Cornell J. L. \& PuB. Pol'y 263 (2007); Marley S. Weiss, Kentucky River at the Intersection of Professional and Supervisory Status - Fertile Delta or Bermuda Triangle?, in LABOR LAW STORIES (Lara J. Cooper \& Catherine L. Fisk eds., 2005); Marion G. Crain, The Transformation of the Professional Workforce, 79 CHI-KENT L. REV. 543 (2004); Harry G. Hutchison, Toward a Robust Conception of "Independent Judgment": Back to the Future?, 36 UnIV. SAN. Fran. L. REV. 335 (2002); Marion G. Crain, Building Solidarity Through Expanding NLRA Coverage: A Blueprint for Worker Empowerment, 74 MinN. L. REV. 953, 972-73 (1990); Matthew W. Finkin, The Supervisory Status of Professional Employees, 45 FORDHAM L. REV. 805 (1977).

202 Doctors' Hosp. of Modesto, Inc., 183 N.L.R.B. 950, 950 (1970), enforced, 489 F.2d 772 (9th Cir. 1973).

203 Id. at 951.

204306 N.L.R.B. 63, 63 n.1 (1992), enforcement denied, 987 F.2d 1256 (6th Cir. 1993), aff'd, 511 U.S. 571 (1994).

205 NLRB v. Health Care \& Ret. Corp. of Am., 511 U.S. 571, 577 (1994).

206 Chairman Gould is the Charles A. Beardsley Professor of Law, Emeritus at Stanford Law School.

207320 N.L.R.B. 717, 725-30 (1996).

208320 N.L.R.B. at 732 (“Charge nurses' daily assignments do not require any independent judgment that goes beyond the professional judgment required of a supervisor."); see also Marley Weiss, Kentucky River at the Intersection of Professional and Supervisory Status - Fertile Delta or Bermuda Triangle?, in LABOR LAW STORIES (Lara J. Cooper \& Catherine L. Fisk eds., 2005), available at http://digitalcommons.law.umaryland.edu/fac_pubs/124/ (detailing "the Battle over Unionization of Supervisors," specifically in the case of Kentucky River). 
divided Supreme Court rejected that interpretation on grounds that the Board's construction inserted "a startling categorical exclusion into statutory text," that goes "beyond the limits of what is ambiguous."209

Following the Supreme Court's rejection of the Clinton Board's construction of "independent judgment," 210 the Bush II Board reversed course in a series of cases known as the Oakwood Trilogy, three cases (two involving nurses) that further broadened the statutory supervisory exemption in light of these Supreme Court rulings. ${ }^{211}$ Piggybacking on Kentucky River, the Board will now consider the greater skilled workers' professional or technical direction of lesser skilled employees in determining whether the greater skilled worker is a supervisor. ${ }^{212}$

The facts of most nurse-supervisor cases are very similar. They occur in a healthcare facility, often an acute-care hospital or nursing home, with several patient-care wings and perhaps as many as several hundred licensed beds. The healthcare facility typically imposes a management structure designed to provide twenty-four-hour, daily, on-site patient care and supervision. The nurses and their assistants (certified nursing assistants or CNAs) often work one of three eight-hour shifts (8 a.m. to 4 p.m., 4 p.m. to midnight, and midnight to 8 a.m., for example), perhaps with half-hour overlaps between shifts so that the nurses can share patient and other information with each other. During the first or day shift and perhaps for part of the second or evening shift, at least one of the several nursing officers remains on-site. Those officers typically include a director of nursing and an assistant director of nursing. There may be a chief nursing officer and other officers, all of who are undisputed supervisors and managers.

There is also typically a first, second, and third shift charge nurse, whose statutory status (prior to Kentucky River and the Oakwood trilogy) might have been in dispute. Charge nurses (RNs or LPNs) oversee their patient care units. They assign staff nurses and CNAs (and perhaps even technicians and paramedics) to patients on their shifts. They monitor patients in their units, meet with doctors, and liaison with patients' family members. They may have their own patient load, but typically not a full load, and often make a little more money for serving as charge nurses. Some charge nurses are permanent (spend all of their time as charge nurse); others rotate, by spending part of their time as staff nurses and part of their time in the role of charge nurse.

\footnotetext{
209 NLRB v. Ky. River Cmty. Care, Inc., 532 U.S. 706, 713-21 (2001) (5-4 decision).

210 Id.

211 Oakwood Healthcare, Inc., 348 N.L.R.B. 686 (2006); Croft Metals, Inc., 348 N.L.R.B. 717 (2006); Golden Crest Healthcare Ctr., 348 N.L.R.B. 727 (2006).

212 Oakwood Healthcare, Inc., 348 N.L.R.B. at 692-94.
} 
Staff registered nurses (RNs) and licensed practical nurses (LPN) provide direct patient care in the patient care units. RNs will implement doctors' orders, administer medication, run blood tests, take vital signs, observe patients, liaison with patients' loved ones, and process admissions and discharges. Staff nurses (RNs or LPNs) will typically instruct lessskilled employees (CNAs, for example) to feed, bathe, turn, or walk patients. Staff nurses may also direct less-skilled employees to perform tests ordered by doctors.

Given facts similar to these, the Bush II Board, in Oakwood, passed on four legal questions:

(1) What is the definition of "assign" within the meaning of Section 2(11)?

(2) What is the definition of "responsibly to direct" within the meaning of Section 2(11)?

(3) What is the definition of "independent judgment" within the meaning of Section 2(11)?

(4) What legal effect does the amount of time a worker spends authorized to exercise one of the enumerated powers with independent judgment have on the question whether that worker is a statutory employee or supervisor?

First, the Bush II Board defined the statutory term "assign," as that word is used in the definition of supervisor, to mean "to appoint to a post or duty." ${ }^{213}$ To avoid overlap with the other 11 enumerated powers, the Bush II Board construed the term "'assign' to refer to the act of designating an employee to a place (such as a location, department, or wing), appointing an employee to a time (such as a shift or overtime period), or giving significant overall duties, i.e., tasks, to an employee. That is, the place, time, and work of an employee are part of his/her terms and conditions of employment. ${ }^{214}$ In the healthcare context, a worker, such as a nurse, engages in the supervisory power of assigning when he directs a staff nurse or other worker to care for a particular patient or when he assigns that employee to a department or a shift or directs that worker to perform a specific task.

Second, the Bush II Board defined the statutory term "responsibly to direct" by focusing on the ordinary definition of responsible as meaning

213 Oakwood Healthcare, Inc., 348 N.L.R.B. at 689.

214 Id. 
accountable. $^{215}$ Construing that statutory term, the Board held that "to be 'responsible,' the person directing and performing the oversight of the employee must be accountable for the performance of the task by the other, such that some adverse consequence may befall the one providing the oversight if the tasks performed by the employee are not performed properly.",216 The Board further specified that, to establish "accountability for purposes of responsible direction," the employer must have "delegated to the putative supervisor the authority to direct the work and the authority to take corrective action, if necessary.", 217 There must also be "a prospect of adverse consequences for the putative supervisor if he/she does not take these steps."218

Third, the Bush II Board, against the background of the Supreme Court's rejection of the Clinton Board's construction of "independent judgment," defined that statutory term by deconstructing it into its two component words. Relying on the ordinary, dictionary meaning of these component words - where independent means " "not subject to control by others" ${ }^{, 219}$ and judgment means " "the action of judging; the mental or intellectual process of forming an opinion or evaluation by discerning and comparing,",220 - the Board held that to exercise independent judgment, "an individual must at minimum act, or effectively recommend action, free of the control of others and form an opinion or evaluation by discerning and comparing data.",221

In partial response to the dissent's criticism, that the Board majority mechanistically relied on the dictionary to construe a statutory term of art, the majority agreed that the dictionary was only a starting point and that it was necessary to consider the NLRA's legislative history, policies, and judicial precedents. $^{222}$ Noting that the plain language of Section 2(11) dictates that "independent judgment" must be construed in light of the contrasting

215 Oakwood Healthcare, Inc., 348 N.L.R.B. at 691, nn.29-34 (observing that several courts of appeals have endorsed this approach) (citing Providence Hosp., 320 N.L.R.B. 717 (1996), overruled on other grounds by NLRB v. Ky. River Cmty. Care, Inc., 532 U.S. 706 (2001), and citing other cases from the First, Fifth, Sixth, Seventh, and Ninth Circuits); See also NLRB v. KDFW-TV, Inc., 790 F.2d 1273, 1278 (5th Cir. 1986) ("To be responsible is to be answerable for the discharge of a duty or obligation. . . . In determining whether 'direction' in any particular case is responsible, the focus is on whether the alleged supervisor is 'held fully accountable and responsible for the performance and work product of the employees' he directs."), quoted in Oakwood Healthcare, 348 N.L.R.B. at 691.

216 Oakwood Healthcare, Inc., 348 N.L.R.B. at 691-92.

217 Id. at 692.

$218 I d$.

219 Id. (citing WeBster's THIRD NEW INTERNATIONAL DiCTIONARY 1148 (1981)).

220 Oakwood Healthcare, Inc., 348 N.L.R.B. at 692 (citing WEBSTER's THIRD NEW INTERNATIONAL DICTIONARY, supra note 219, at 1223).

221 Id. at 692-93.

222 Id. at 693. 
language, "'not of a merely routine or clerical nature,",223 and relying on the Supreme Court's observation that independent judgment must lie somewhere between action that is completely free and action that is completely controlled by others, the Board held that it "must assess the degree of discretion exercised by the putative supervisor." 224

The Board held that "judgment is not independent if it is dictated or controlled by detailed instructions, whether set forth in company policies or rules, the verbal instructions of a higher authority, or in the provisions of a collective-bargaining agreement." ${ }^{225}$ Immediately undercutting that position, the Board further commented that "the mere existence of company policies does not eliminate independent judgment from decision-making if the policies allow for discretionary choices."226

Fourth and finally, the Board held that " $[\mathrm{w}]$ here an individual is engaged a part of the time as a supervisor and the rest of the time as a unit employee, the legal standard for a supervisory determination is whether the individual spends a regular and substantial portion of his/her work time performing supervisory functions."227 The Board clarified that under its standard, "regular' means according to a pattern or schedule, as opposed to sporadic substitution. The Board has not adopted a strict numerical definition of substantiality and has found supervisory status where the individuals have served in a supervisory role for at least 10-15 percent of their total work time." 228

The Board proceeded to apply those legal principles to three cases all decided on the same day. First, in Oakwood, the Board found that 12 permanent charge nurses were statutory supervisors because they exercised the authority to assign nursing personnel to patients and to responsibly direct other less-skilled workers with the requisite independent judgment. ${ }^{229}$ The Board further found that because the employer failed to meet its burden of showing that the rotating charge nurses regularly served as charge nurses, it need not decide whether they exercised supervisory authority for a substantial part of their work time. ${ }^{230}$

223 Id. (quoting 29 U.S.C. § 152(11) (2006)).

224 Oakwood Healthcare, Inc., 348 N.L.R.B. at 693 (citing NLRB v. Ky. River Cmty. Care, Inc., 532 U.S. 706, 713-14 (2001)).

225 Id. at 693.

226 Id.

227 Id. at 694.

228 Id.

229 Id. at 694-95.

230 Id. at $698-99$. 
In Bev Enterprises-Minnesota, Inc. (Golden Crest Health Care Center), ${ }^{231}$ the Board applied these legal principles to another set of charge nurses. There, it held that the nurses' authority to "request" that the aides "stay past the end of their shifts or . . . to come in from home" or work on a particular floor did not constitute the authority to "assign," absent a showing of authority to require that. ${ }^{232}$

And in Croft Metals Inc., ${ }^{233}$ the Board applied these principles to a lead person at a manufacturing facility. There it found that these lead persons did not have the authority to assign other employees to "production lines or departments or to shifts over overtime periods" and that "the occasional switching of tasks ... d $[\mathrm{id}]$ not implicate the authority to "assign"' as constructed by the Board. ${ }^{234}$ The Board further found that these lead persons did "responsibly direct" others because the record showed that they could "discipline" with "written warnings," 235 but that the employer had failed to show that this responsible direction was exercised with the requisite independent judgment involving "a degree of discretion that rises above the "merely routine or clerical.",236 Instead, the lead person established a delivery schedule and generally used a standard loading pattern that dictated the placement of different products in the trucks.

The dissent criticized the Board majority's analysis as being "both inconsistent with the statutory text and structure and inferior to alternative interpretations." ${ }^{237}$ Along those lines, in addition to offering specific reasons for rejecting the majority's construction of the supervisory exemption, the dissent made an overarching criticism of the majority's approach. In the dissent's view, the majority's reliance on dictionary definitions results in an overly formalistic analysis that ignores the statutory context of the statutory exemption, ${ }^{238}$ the legislative purpose of that exemption, and the realities of such a far-reaching exemption. Along these lines, the majority's analysis fails to read the exemption in statutory context and therefore creates an interpretation of Section 2(11) that is incoherent.

In particular, as a matter of statutory construction, the dissent found that the majority's "largely dictionary-driven approach" ignored the structural architecture of the Act, which "explicit[ly] recogni[zed] that professionals, and certain persons who perform work under the supervision of

231 Beverly Enters.-Minn, Inc., 348 N.L.R.B. 727 (2006).

232 Id. at 729.

233 Croft Metals, Inc., 348 N.L.R.B. 717 (2006).

234 Id. at 722.

235 Id.

236 Id.

237 Oakwood Healthcare, Inc., 348 N.L.R.B. at 702.

238 Id. at 703-09. 
professionals, may be statutory employees." 239 The dissent acknowledged that, using an isolated, noncontextual, formalistic approach could generate the majority's result. But that result is incoherent because it disenfranchises any professional who directs the work of or assigns work to any subordinate, regardless of that professional's supervisory or managerial reality i.e., most professionals. In the dissent's view, contrary to the congressional intent to "distinguish[] between straw bosses, leadmen, set-up men, and other minor supervisory employees, on the one hand, and the supervisor vested with such genuine management prerogatives, ${ }^{240}$ the majority's decision thereby "threatens to create a new class of workers . . . who have neither the genuine prerogatives of management, nor the statutory rights of ordinary employees." 241 The economic reality, then, is that the majority's rule disempowers a portion of the middle class - as many as 34 million by 2012 - who has neither power (supervisory/managerial) nor autonomy (voice) at the workplace. ${ }^{242}$ The economic impact of the majority's rule is compounded by its disenfranchisement of part-time supervisors, such as rotating charge nurses, who spend as little as ten percent of their time exercising minimal supervisory authority.

\section{Implications for Professional Employees ${ }^{243}$}

The policy reasons for disenfranchising supervisors and even most independent contractors are unclear. After all, the Railway Labor Act, which covers certain common carriers not covered by the NLRA, and many state statutes, which cover public employees not covered by the NLRA, have allowed supervisors and foremen to unionize with no problems. For example, under the Railway Labor Act, protected employees include "every person in the service of a carrier . . . who performs any work defined as that of an employee or subordinate official ..."244 The use of the term "subordinate official" has been interpreted to include workers with substantial responsibilities. ${ }^{245}$

Notwithstanding the experience under these statutes, the Supreme Court and now the Bush II Board have been reluctant to protect workers with even the most minor responsibilities who organize. The Oakwood

239 Id. at 701.

240 Id. at 701 .

241 Id. at 700 .

242 Id.

243 For further insights into this issue, see, for example, law review articles cited supra note 201.

24445 U.S.C. $\$ 151$, Fifth.

245 See, e.g., Dorsey v. United Parcel Serv., 195 F.3d 814, 817-18 (6th Cir. 1999) (holding that workers, who occupy the position of flight training supervisor or assistant chief pilot are statutory employees). 
trilogy, for example, is infamous not only for expanding the definition of the statutory term independent judgment in a manner that tends to swallow professional employees, but also for otherwise expanding the supervisor exemption in a way that punches a gaping hole in the otherwise seemingly broad statutory definition of employee. By coupling broad definitions of "assign" and "responsibly to direct" with such a broad conception of "independent judgment," the Board makes concrete the concerns of the Kentucky River and Oakwood dissents - that most professional employees are no longer covered by the NLRA. The trilogy then goes beyond Kentucky Riv$e r$ by finding supervisory status among workers who merely exercise supervisory authority on a rotating basis.

But even before Kentucky River or the Oakwood trilogy ever issued, reviewing courts were narrowing the definition of employee as it applied to professional employees through the managerial exemption. Thus, in NLRB v. Bell Aerospace Co., ${ }^{246}$ the Court directed the Board to clarify this exemption. On remand, the Board defined managerial employees:

as those who formulate, determine, and effectuate an Employer's policies .... . [T] he determination of an employee's 'managerial' status depends upon the extent of his discretion, although the authority to exercise considerable discretion does not render an employee managerial where his decision must conform to the employer's established policy.

. . . as those who formulate and effectuate management policies by expressing and making operative the decisions of their employer, and those who have discretion in the performance of their jobs independent of their employer's established policy . . . managerial status is not conferred upon rank-and-file workers, or upon those who perform routinely, but rather it is reserved for those in executive-type positions, those who are closely aligned with management as true representatives of management. $^{247}$

Although the Board ultimately concluded that the workers at issue in Bell Aerospace Co. - buyers in the purchasing and procurement department of a plant engaged in research and development of aerospace products were statutory employees and not managers because those workers "did not exercise sufficient independent discretion in their jobs to truly align them with management," 248 the legal precedent set under this line of cases

\footnotetext{
246416 U.S. 267 (1974).

247 Bell Aerospace, 219 N.L.R.B. 384, 385-86 (1975).

248 Id.
} 
endorses the view that managers, even low-level managers, are exempted from NLRA coverage. This is so notwithstanding the Act's plain language, which does not expressly exempt such workers. Indeed, even some confidential employees, who work for managers, but are not themselves managers, are also excluded from the Act if they have access to confidential personnel-type information. ${ }^{249}$

And in NLRB v. Yeshiva University, ${ }^{250}$ the Supreme Court held that full-time faculty members of Yeshiva University, a large, private educational institution, were all managerial employees because of the faculty's role in faculty appointments, setting curriculum, grading, admission standards, course scheduling, and its "crucial role . . . in determining other central policies of the institution." ${ }^{251}$ The Court rejected the Board's argument that the faculty members were not managers on grounds that the faculty members exercised "independent professional judgment" when discharging their duties, which in this case required the faculty members to align themselves with management. $^{252}$ The Court found the distinction between independent managerial judgment and independent professional judgment simply to be unpersuasive here, where the Court found no distinction between the faculty's professional interests and the interests of the institution - "the business of a university is education."

In sum, these managerial cases grow out of the same obsessive concern that drove the supervisory exemption: "That an employer is entitled to the undivided loyalty of its representatives." 254 That concern is inconsistent with the core values of a just industrial democracy built on worker autonomy and dignity.

\section{E. Implications for the Autonomous Dignified Worker}

Neither the independent contractor nor the supervisory exemption, as drafted and construed, is compatible with the autonomous dignified worker. As a threshold matter, neither definition promotes worker autonomy. This

249 In Ford Motor Co., the Board held that confidential employees are those who "assist and act in a confidential capacity to persons who exercise "managerial' functions in the field of labor relations." 66 N.L.R.B. 1317, 1322 (1946) (creating the labor-nexus test). In NLRB v. Hendricks County Rural Electric Membership Corp., the Supreme Court upheld the Board's labor nexus test. NLRB v. Hendricks County Rural Elec. Membership Corp., 454 U.S. 170, 188 (1981) (holding that some confidential employees, specifically those who have access to confidential personnel information, are exempted from the Act's coverage).

250444 U.S. 672 (1980).

251 Id. at 679.

252 Id. at 683-85.

253 Id. at 688.

254 Id. at 682. 
is most clearly demonstrated with independent contractors. Only those workers subjected to sufficient control and subordination are deemed employees under the common law test. Although the Board has clarified that the independent contractor analysis should not be reduced to one factor, $^{255}$ control permeates each factor of the Restatement's multi-factored common-law test. So while the full-time cook might retain creative control over her culinary menu, she still remains under the control of her employer in other ways or she is not an employee. ${ }^{256}$ So, too, with supervisors and managers - the more independent judgment or discretion they exercise, the less likely they are to be protected.

Nor do these exemptions dignify workers. Indeed, the supervisory exemption expressly de-dignifies workers by rationalizing a labormanagement binary with workers ("husbandmen and craftsmen") relegated to having bronze souls ${ }^{257}$ and the owners, who possess gold souls, have "the power of command." ${ }^{258}$ Supervisors and managers are the soldiers, whose silver souls are designed "to be auxiliaries"259 to those who command. Supervisors and managers must, therefore, be aligned with owners to maintain this binary. In this "dream" or delusion imposed on silver and bronze workers by the ruling gold class, independent contractors are themselves aspiring gold people, who must compete with the other gold people for the economy's resources.

This analysis leads to one fairly straightforward observation: The statutory exemptions are inconsistent with promoting a workplace that values the autonomy and dignity of its workers. Accordingly, either the autonomous dignified worker theory is flawed and should not serve as a foundation for workplace legal policies or the NLRA is fundamentally flawed by failing to reflect these values at the very gateway of protection. ${ }^{260}$

255 Roadway Package Sys., Inc., 326 N.L.R.B. 842, 848, 850 (1998) (rejecting employer's contention that "the right to control the manner and means of accomplishing the end result is the 'most important' factor or 'predominant' consideration in determining the individual's status").

256 RESTATEMENT (SECOND) OF AGENCY § 220(1), cmt.d. (1958).

257 PLATO, supra note 106, at 177-78.

258 Id. at 177

259 Id.

260 Indeed, the Court's interference with workers' right to organize has been so deeply felt by the labor community that it has taken the bold step of filing a complaint with the International Labor Organization. See Complaint by the American Federation of Labor and Congress of Industrial Organizations to the ILO Committee on Freedom of Association Against the Government of the United States of America for Violation of Fundamental Rights of Freedom of Association and Protection of the Right To Organize and Bargain Collectively Concerning Employees Classified as "Supervisors" Under the National Labor Relations Act, filed Oct. 23, 2006, http://www.aflcio.org/joinaunion/voiceatwork/upload/ ilo_complaint.pdf. The ILO recently ruled in the AFL-CIO's favor. See 349th Report of the Committee on Freedom of Association at 184-202 (Mar. 2008), http://www.ilo.org/wcmsp5/groups/public/--ed_norm/---relconf/documents/meetingdocument/wcms_091464.pdf. 


\section{CONCLUSION: RECONSTRUCTING \\ THE STATUTORY DEFINITION OF EMPLOYEE}

Deconstructing the statutory definition of employee shows that the Board and the NLRA are not simply withering away but that the protections embodied in the labor act have been eroded by several actors - Congress, the courts, and, in some cases, the Board itself. That erosion has mostly been to broaden the negative aspect of the statutory definition of employee, not only by congressional amendment, but also by judicial amendment and even by administrative oscillation. ${ }^{261}$

The courts have made one of their most ominous marks on the supervisory exemption. The Supreme Court has twice struck down the Board's attempt to read that exemption narrowly to include as many minor bosses and professional workers as possible. In the Oakwood trilogy, the Bush II Board further eroded the definition by reversing course and broadly interpreting the supervisory powers of assignment and responsible direction.

In another article, I argue that congressional enactment of the Re-Empowerment of Skilled and Professional Employees and Construction Tradeworkers (RESPECT) $\mathrm{Act}^{262}$ would go a long way toward putting the autonomous dignified union worker back to work. ${ }^{263}$ The RESPECT Act would have the immediate effect of overruling the Board's recent Oakwood trilogy by narrowing the definition of supervisor in two ways. First, the Act would remove the authority to assign and to responsibly direct other employees as conditions for finding supervisory status. Second, the Act would require workers to possess supervisory authority over employees for a majority of that worker's work time. This would reverse the Board's policy, explicated in the Oakwood trilogy, of finding supervisory status in cases where employees exercise supervisory powers in as little as ten percent of their work time.

The question whether the RESPECT Act is likely to empower workers depends in part on the type of litigation that could arise from its enactment. The RESPECT Act would obviously spark litigation over the extent to which a worker's time is spent discharging supervisory powers. What is less obvious is that the RESPECT Act is also likely to spark litigation over the putative supervisor's other powers, especially disciplinary power and the power to "effectively ... recommend such action." ${ }^{264}$ By eliminating

\footnotetext{
261 See generally Union Repression, supra note 13; September Massacre, supra note 13.

262 H.R. REP. NO. 1644, 110th Cong. (2007), available at http://www.govtrack.us/congress/ billtext.xpd?bill $=\mathrm{h} 110-1644$.

263 This discussion of the RESPECT Act is taken largely from, and originally published in, The Persistence of Union Repression in an Era of Recognition, 62 ME. L. REV. 199, 233 (2010).

26429 U.S.C. § 152(11) (2006).
} 
the powers to assign and responsibly to direct from the twelve enumerated powers, and by retaining the authority to "hire, transfer, suspend, lay off, recall, promote, discharge, . . . reward ... discipline . . . or to adjust [employee] grievances, "265 the RESPECT Act essentially limits the supervisory exemption to those employees who have authority over other employees where authority entails one person's actual power over another person. While, from the employee's perspective, this seems like the right move, such legislation may very well backfire if courts misunderstand the significance of the amendment and begin to find that workers hold the power to discipline in cases where there is very little authority, such as in cases where workers are merely reporting work transgressions to true supervisors and managers. $^{266}$

The legacy of the independent contractor exemption is less obvious. Although one of the main goals of those who supported that exemption was to limit the Board's discretion to distinguish between employees and independent contractors, the results have been mixed. Certainly the Board has been limited to applying the common law agency test in distinguishing between statutory employees and independent contractors, but, given the multi-factor, circumstantial nature of the test, the Board has had, in many cases, ample room to interpret the factual record to find either employee or independent contractor status. Accordingly, the results of applying that test are likely to depend on the political composition of the Board and the ideological leanings of its members.

And perhaps the untold story is about the Board itself, which has made the most pernicious contribution by attacking the affirmative aspect of the definition - even in light of the court-approved broad construction of employee. By limiting the statutory definition to only those workers whose relationship with their employer is predominantly economic, and then applying that broad definition to students, disabled workers, and salts, the Board has gauged a gaping hole in the heart of the statutory definition of employee that is hardly natural.

Given these problems with the statutory exemptions, I would go farther than the RESPECT Act and eliminate by congressional amendment the supervisory and independent contractor exemptions as well as the managerial exemption that has been read into the Act. I would also expressly

265 Id.

266 Compare Hosp. Gen. Menonita v. NLRB, 393 F.3d 263, 267-68 (1st Cir. 2004) (holding that evidence is insufficient to demonstrate supervisory status "where an employee's involvement in the evaluation process is merely reportorial in nature"), with NLRB v. Quinnipiac Coll., 256 F.3d 68, 76-77 (2d Cir. 2001) (overturning Board finding and holding that evidence is sufficient to demonstrate supervisory status where employees "have the discretion whether to report an individual for disciplinary infractions"). 
overrule the Bush II Board's "predominantly economic" test. The freedom to band together for mutual aid or protection should be protected as a fundamental right of all workers. The United States, as the self-declared leader of the "free world," should behave as a leader, set an example, and take seriously the freedom to associate, which includes the right of workers to band together in common cause.

This proposal, of course, has no chance of passing in the near future. But perhaps less radical changes could pass. The problem is coming up with less radical solutions to the problem of class struggle. One possibility is to eliminate these exemptions, or at least the supervisory exemption, for very large employers with a multi-tiered hierarchical structure. Again, this would take congressional amendment, but a case could be made that the balance of power in those organizations is sufficiently warped to justify the change, at least to those moderate pro-business policymakers who believe in the basic policies underlying the NLRA.

A less radical solution, for the problems associated with exempting independent contractors from statutory coverage, is more complex. Given the likelihood that the ideological leanings of board members change with elections, which in turn contribute to less stable and predictable results, the Board should at least adopt (and consistently apply) the principle that the purpose in applying the common law agency test is to effectuate the purposes of the NLRA, which includes protecting workers. It is well-known that the test for independent-contractor status is applied differently depending on the context in which it is being applied. So, for example, that test tends to be applied with an eye toward protecting workers when applied for purposes of worker compensation statutes and is applied with an eye toward protecting third parties when applied in the vicarious liability context. Distinguishing between a statutory employee and an independent contractor for purposes of the NLRA should be accomplished with an eye toward protecting Section 7 rights. While the Obama Board could make this statement through adjudication, it would be less subject to administrative oscillation if achieved through rulemaking. ${ }^{267}$

267 Along these lines, labor law is in line to continue to suffer from one-step-forward-two-stepsbackward oscillation for as long as the Board continues to be comprised of members with political ideologies. I thus agree with many of the comments regarding oscillation made by former board member Dennis Walsh recently made at the ACS Event: The National Labor Relations Act at 75 - Looking Back, Looking Forward. There, Member Walsh remarked on effects of an increasingly politicized board, short-term board members, long-term recess appointments, and the need to fix the appointment process through, among other things, hold-over appointments. That panel discussion is available at http://www.acslaw.org/node/16126. Member Walsh also had many reservations about rulemaking. For a more in-depth discussion of the pros and cons of NLRB rulemaking, see Jeffrey S. Lubbers, The Potential of Rulemaking by the NLRB, 5 FIU L. REV. 411. 
Another less radical solution is to amend the NLRA by defining independent contractor more along the lines of the economic realities test, by which the court examines a variety of factors, including:

- "the degree of control that the putative employer has over the manner in which the work is performed;"

- 'the worker's opportunity for profit or loss dependent on his managerial skill;",

- 'the worker's investment in equipment or material, or his employment of other workers;",

- "the degree of skill required for the work;"

- "the permanency of the working relationship;"

- "the degree to which the services rendered are an integral part of the putative employer's business." 268

It is unclear, however, whether the economic realities test, which is "designed to capture the economic realities of the relationship between the worker and the putative employer," 269 would actually make any difference in application. So perhaps the better solution is to create what Canada has, the distinction between the independent contractor, who does not have collective-bargaining rights, and the dependent contractor, who does have collective-bargaining rights. Dependent contractors, as defined under the Canadian Code, are

any other person who, whether or not employed under a contract or employment, performs work or services for another person on such terms and conditions that they are, in relation to that other person, in a position of economic dependence on, and under an obligation to perform duties for, that other person. ${ }^{270}$

This definition has the advantage of keying in on the value of worker autonomy vis-á-vis the employer. And while I see no good reason to disenfranchise even a truly autonomous, independent contractor, introducing the concept of a dependent contractor would go a long way toward capturing at least the most vulnerable contractors.

But no policy, radical, moderate, or otherwise, will help workers band together for mutual aid or protection unless workers have class conscious-

268 See Schultz v. Capital Int'1 Sec., Inc., 466 F.3d 298, 304-05 (4th Cir. 2006).

269 Id. at 305.

270 See Judy Fudge, A Canadian Perspective on the Scope of Employment Standards, Labor Rights, and Social Protection: The Good, the Bad, and the Ugly, 31 CoMP. LAB. L. J. 253, 259-60 (2010) (quoting Canada Labour Code, R.S.C., ch. L 2, s.3(1) (1985)). 
ness. And even though both unions and big business have image problems (unions are perceived as wedded to organized crime and big business is currently perceived as greedy), big business has historically controlled the media and its messages. ${ }^{271}$ Perhaps the best chance of revitalizing the union movement then is to ensure organizational rights through the internet. After all, it doesn't matter how many workers are "protected" by the NLRA, if there is nothing to protect. If I am right, the most important battleground in putting the autonomous dignified union worker back to work will be how the Obama Board and subsequent boards handle real and virtual workplace organizing using modern technology such as Facebook and other social networks.

271 Corporate control over the media is likely to grow worse with the Supreme Court's decision in Citizens United v. FEC, 130 S. Ct. 876, 886 (2010) (holding that it is not constitutionally permissible under the First Amendment for the government to suppress political speech on the basis of the speaker's corporate identity or to bar independent corporate expenditures for electioneering through federal statutory law) (overruling Austin v. Mich. Chamber of Commerce, 494 U.S. 652 (1990), and McConnell v. FEC, 540 U.S. 93 (2003)). A discussion of how corporations are likely to benefit more from Citizens United than unions is beyond the scope of this article.

272 See generally Jeffrey M. Hirsch, Communication Breakdown: Reviving the Role of Discourse in the Regulation of Employee Collective Action, http://papers.ssrn.com/sol3/papers.cfm?abstract_id= 1553031; Jeffrey M. Hirsch, The Silicon Bullet: Will the Internet Kill the NLRA?, 76 GEO. WASH. L. REV. 262 (2008). 